\title{
8 Everyone's Friend? Das AFSC, der Zweite Weltkrieg und die Spannungen der humanitären Hilfe nach 25 Jahren
}

Auf allzu großen Zuspruch der Öffentlichkeit durfte das AFSC nicht hoffen, als es sich im Juni 1943, auf dem Höhepunkt des Zweiten Weltkriegs, in Stellung brachte, um der deutschen Bevölkerung nach einem zukünftigen alliierten Sieg als erste auswärtige Agentur humanitäre Hilfe zu leisten. Dennoch sah man sich genau für diese Aufgabe prädestiniert: „Our moral prestige is high“, hieß es im Eingangsstatement einer Strategiedebatte der foreign service section. „Everywhere Friends are known for their integrity, devotion, absence of fear, and humanitarianism“, ihre Loyalität gelte „not any one country, political group, sectarian group (...). We can be - and I think we are - everyone’s friend. “Aus dieser Position erwachse den Quäkern die Freiheit und mithin die Verantwortung, „to pick up some less popular tasks“. Die Versorgung der Bevölkerung in den künftig ehemaligen Feindgebieten war dabei nicht nur moralisches Gebot. Hunger und Seuchen und damit den Zusammenbruch der sozialen Ordnung zu vermeiden, würde, so die Einschätzung, nach aller Erfahrung im Interesse der Besatzungsmacht liegen. Wo andere Hilfsagenturen vor der Aufgabe zurückscheuten, stehe das AFSC, immer schon „the helper of unpopular groups“, bereit. Aus diesem Blickwinkel waren der quäkerliche, auf Versöhnung zielende Ansatz und die Hilfe für „unpopuläre“ Gruppen als Dienstleistung zugunsten der künftigen Besatzungsmacht eins. Solche Hilfe war folglich „not only an important tradition but a specific function“. ${ }^{1}$

Deutlich wird in dieser Episode, welch langen Weg das AFSC in dem knappen Vierteljahrhundert seiner Geschichte zurückgelegt hatte. Der Zweite Weltkrieg bietet in dieser Hinsicht viele Ansatzpunkte für eine Bestandsaufnahme, auch was die Spannungen der humanitären Hilfsaktivitäten betrifft. In mancher Hinsicht kehrte das Komitee in dieser Zeit zu seinen Wurzeln zurück. Erneut sah sich das Komitee vor die Aufgabe gestellt, Gewissensverweigerern eine Alternative zum Dienst an der Waffe zu bieten, wieder stellte sich die Frage, was „constructive service“ in Kriegszeiten für die Quäker bedeutete. Auch das Verhältnis zu den britischen Glaubensgenossen, die richtige Balance zwischen message und relief work, und die Definition des eigenen Standpunktes in Fragen internationaler Zusammenarbeit rückten erneut in den Fokus.

1 Confidential Memorandum: Debate among foreign service staff of AFSC with friends on postwar planning 4/6 und 5/6/1943, in: AFSCA, AFSC Minutes 1943.

Ә OpenAccess. (C) 2022 Daniel Maul, publiziert von De Gruyter. (cc) BY-NC-ND Dieses Werk ist lizenziert unter einer Creative Commons Namensnennung - 4.0 International Lizenz. 
Gleichzeitig war vieles nun aber auch ganz anders als nach 1914. Der gravierendste Unterschied war die Existenz des AFSC selbst. Erfahrungen, Mechanismen und Verbindungen aus 23 Jahren flossen nun in den Umgang mit der neuen Ausnahmesituation ein. Was das AFSC von 1939 auszeichnete, war das Selbstbewusstsein einer etablierten Hilfsorganisation, die sich in vieler Hinsicht von der defensiven Position der Quäker im April 1917 abhob.

\section{Wieder im Krieg. Das AFSC 1939-1941}

Nach Kriegsbeginn im September 1939 glich die Situation des AFSC rein äußerlich der Lage der US-Quäker vor dem April 1917: Während Europa und die britischen Glaubensgenossen im Krieg litten, konnten die amerikanischen Quäker ihre Haltung aus einer Position heraus bestimmen, in der sie das Geschehen gleichzeitig von außen und innen betrachteten. Clarence Picketts Bericht über die Tätigkeit des AFSC während der ersten Kriegsmonate von Anfang 1940 veranschaulichte diesen Prozess teilnehmender Beobachtung eindrücklich. Pickett entwarf zunächst ein Panorama der Tätigkeit in den ersten Kriegsmonaten: In Frankreich unterhielten die Quäker Kinderkolonien für spanische Kriegswaisen und arbeiteten im Zusammenspiel mit der International Commission in den Lagern für republikanische Flüchtlinge. ${ }^{2}$ Auch die Hilfe für deutsche Flüchtlinge in ganz Europa und den USA lief weiter. Von den britischen Quäkern hatte das AFSC die Leitung der internationalen Zentren in Wien und Berlin übernommen. Mit neuen Quäkerstützpunkten in Amsterdam, Kopenhagen und Shanghai vergrößerte sich mit amerikanischer Unterstützung das Netz der Hilfe. Zeitgleich bereiste eine Reihe von „travelling friends“ mögliche Aufnahmeländer für deutsche Flüchtlinge in Europa und Südamerika und die Zusammenarbeit mit dem JDC in Europa und den USA wurde weiter ausgebaut.

In den USA sah sich das AFSC indes auf dem Höhepunkt seines Ansehens. Anfang 1940 konnte Clarence Pickett auf eine Reihe von öffentlichen Auszeichnungen und eine überwiegend günstige Presse verweisen, die sich ,embarrassingly approving of our work“ zeige. ${ }^{3}$ Eng wie nie zuvor war auch das Verhältnis zum Weißen Haus, dokumentiert durch eine Vielzahl von Besuchen Picketts und die häufige Korrespondenz mit Roosevelt und der First Lady in den ersten Monaten nach Kriegsbeginn. Im April 1940 hielten sich gar hartnäckig Gerüchte, der

2 Bericht von Clarence Pickett für das Jahr 1939 26/1/1940, in: AFSCA, AFSC Minutes 1940.

3 Bericht von Clarence Pickett für das Jahr 1939 26/1/1940, in: AFSCA, AFSC Minutes 1940. 
Präsident habe Pickett für den Botschafterposten in Deutschland designiert. ${ }^{4}$ Unabhängig von der Ernsthaftigkeit solcher Pläne - in vieler Hinsicht konnte das AFSC sich in seiner Arbeit bestätigt fühlen. Pickett gab sich dennoch keinen übertriebenen Illusionen hin. Vieles sei der momentan noch vorherrschenden Anti-Kriegs-Stimmung im Land geschuldet. Dabei sei allerdings Vorsicht geboten: „While one is grateful for this approval, we must keep in mind that our spiritual emphasis and our pacifist convictions might well, under changed conditions, quite reverse this public approval." ${ }^{5}$ Die Vorsicht sollte sich als nur zu begründet erweisen.

Einen ersten Indikator lieferte Polen, wo sich das AFSC seit Kriegsausbruch um Zugang für einen Hilfseinsatz bemühte. Bereits in den ersten Wochen nach dem deutschen Überfall im September 1939 waren entsprechende Vorbereitungen über das Berliner Zentrum angelaufen, die sich nach dem Ende des Feldzugs im Oktober und der folgenden Aufteilung Polens unter Deutschland und der Sowjetunion weiter konkretisierten.

Die geplante Hilfsaktion für die polnische Zivilbevölkerung traf in der amerikanischen Öffentlichkeit von Anfang an auf scharfe Kritik. Dabei spielte zunächst eine Rolle, dass die Deutschen solche Hilfe nur im besetzten (das heißt nicht direkt annektierten) Teil des Landes, im sogenannten Generalgouvernement, zulassen wollten. Hierhin hatten die Sieger im Rahmen ihrer rassistischen „Umvolkungspolitik“ rund eine Million Menschen aus Westpolen deportiert, für deren Versorgung die Besatzer keine eigenen Ressourcen aufwenden wollten. Kritiker, darunter auch die britische Regierung, bemängelten vor diesem Hintergrund, dass humanitäre Hilfsleistungen zuallererst der deutschen Militärmacht zu Gute kämen, die auf diese Weise von Besatzungskosten befreit würde.

Zeitgleich formierte sich in den USA eine Commission for Polish relief (kurz: Comporel), die unter anderem auf die Unterstützung Herbert Hoovers zählen konnte und den Quäkern eine Zusammenarbeit anbot. ${ }^{6}$ Im Oktober nahm Homer Morris für das AFSC als Teil einer Delegation in Warschau Verhandlungen mit den deutschen Besatzern auf. Die Gespräche gerieten jedoch schnell in eine Sack-

4 Lawrence McK. Miller, Witness for Humanity: A Biography of Clarence E. Pickett (Wallingford, PA: Pendle Hill Publications, 1999), 201.

5 Bericht von Clarence Pickett für das Jahr 1939 26/1/1940, in: AFSCA, AFSC Minutes 1940.

6 Allgemein zu Hoovers erneuter Rolle in der Organisation humanitärer Einsätze im Zweiten Weltkrieg (zuvor bereits in der Finnlandhilfe nach der sowjetischen Invasion 1939) siehe James H. George, „Another Chance: Herbert Hoover and World War II Relief.“ Diplomatic History 16, 3 (1992), 389-407. 
gasse, auch weil Deutschland nicht bereit war, der Aufnahme der jüdischen Bevölkerung in ein Speisungsprogramm zuzustimmen. ${ }^{7}$

Im Rahmen der Gespräche wurde zur selben Zeit das gewandelte Selbstbewusstsein des AFSC deutlich. Ein geheimes Memorandum des AFSC skizzierte im März 1940 die Verhandlungen, die das Komitee, auch im Namen von Comporel, mit Vertretern des Auswärtigen Amtes, dem Deutschen Roten Kreuz sowie dem Generalgouverneur Hans Frank über einen Einsatz führte. Da die Deutschen Comporel als pro-polnisch betrachteten, hielt das AFSC es für angezeigt, lieber allein zu agieren, um die eigene Position in Polen nicht zu gefährden. Die Quäker wollten ihre Hilfe zwar eng mit Comporel koordinieren und deren Weisungen folgen, darüber hinaus jedoch, vermerkte das Memorandum, ,it was agreed that the situation in Poland would be best served by AFSC retaining its own identity and functioning as an independent Quaker administrative agency“. Sich Comporel unterzuordnen, sei auch deshalb kontraproduktiv, hieß es weiter, da „Friends have their own methods of work and their own long established relationships with the German government“".

Was Polen betraf, erwiesen sich diese Planungen allerdings spätestens mit Beginn des Krieges im Westen im Mai 1940 als obsolet. Alle Türen für eine Hilfsaktion schlossen sich und Comporel konzentrierte seine Tätigkeit im Wesentlichen auf polnische Flüchtlinge außerhalb des Mutterlandes. Im Westen besetzten deutsche Truppen im Laufe des Frühjahres Norwegen, Dänemark, Belgien und die Niederlande, im Juni kapitulierte auch Frankreich. Damit verblieb Großbritannien als alleinige Bastion gegen den Vormarsch der Nazis in Europa. Vor diesem Hintergrund begannen auch die USA ihre neutrale Haltung Schritt für Schritt aufzuweichen. Manifest wurde dies spätestens im Dezember als Präsident Roosevelt das Land als „great arsenal of democracy“ in Stellung brachte. Im LendLease Act vom März 1941 folgte dann die praktische Umsetzung. Von da an befanden sich die USA faktisch an der Seite Großbritanniens in einem unerklärten, passiven Kriegszustand mit den Achsenmächten. Die Atlantik-Charta vom August 1941, in der beide Länder gemeinsame Ziele für die neue Weltordnung nach dem Ende des Krieges definierten, war nur ein weiterer Ausdruck dieser Tatsache, bevor der japanische Angriff auf Pearl Harbor den letzten, entscheidenden Anstoß für einen Kriegseintritt der USA gab.

7 Zur Arbeit von Comporel siehe Merle Curti, American Philanthropy Abroad (New Brunswick, NJ: Rutgers University Press, 1963), 414-416. Zur Rolle der Quäker Hans A. Schmitt, Quakers and Nazis: Inner Light in Outer Darkness (Columbia: University of Missouri Press, 1997), 177-178.

8 Geheimes Memorandum on Polish Work, Poland Committee 14/3/1940, in: AFSCA, AFSC Minutes 1940. 
Ein Strom von besorgniserregenden Nachrichten aus den europäischen Quäkerzentren begleitete diese Geschehnisse und machte die Folgen unmittelbar greifbar. So berichtete Irene Pickard aus Genf nach der deutschen Invasion Frankreichs im Mai 1940 von Vorkehrungen für eine Evakuierung des Internationalen Zentrums für den Fall, dass die neutrale Schweiz ebenfalls ins Visier der Nazis geraten sollte. ${ }^{9}$ Das Genfer Zentrum, in dem Gilbert MacMaster die amerikanische Vertretung übernahm, wurde in den Jahren des Krieges eine Insel, in der amerikanische und britische Quäker weiterhin ihre Arbeit koordinieren konnten. ${ }^{10}$ Bedrohlich war zur selben Zeit auch die Lage in Frankreich selbst, wo die Kapitulation Ende Juni sowohl die Arbeit des Quäkerzentrums für die deutschen Exilanten als auch die der International Commission für die spanischen Flüchtlinge in den Lagern des Südens in Frage stellte. Die amerikanischen Quäker bereiteten sich darauf vor, die Verhandlungen mit den deutschen Siegern in Eigenregie zu führen, und Howard Elkinton im Berliner Zentrum fiel die Aufgabe zu, die deutsche Regierung über die ,impartial and non-political nature of this work“ zu informieren. ${ }^{11}$

Das AFSC hatte zu diesem Zeitpunkt sechs Helfer im Süden Frankreichs, die sowohl für spanische Kinder, für französische Evakuierte als auch für belgische und holländische Flüchtlinge arbeiteten. ${ }^{12}$ Mit Hilfe privater Spenden gelang es dem AFSC unter der Leitung Howard Kershners im folgenden Jahr, die Arbeit aufrechtzuerhalten. „This service (...) represented to thousands of men, women, and children confined in concentration camps the difference between a starvation diet and something approaching subsistence.“ Für den August und September 1942 fand sich dann über Berichte von „refugees (who) were deported in large numbers to Poland“ auch der Hinweis auf die Deportationen aus dem unbesetzten Teil Frankreichs in die Vernichtungslager des Ostens. ${ }^{13}$

9 Irene Pickard (Genf) an Clarence Pickett 18/5/1940, in: AFSCA, AFSC Minutes 1940.

10 AFSC Annual Report 1941, 14.

11 Emergency Relief Committee 11/6/1940, in: AFSCA, AFSC Minutes, European Relief committee 1940.

12 AFSC Annual Report 1941, 6-7. Clarence Pickett bat parallel auch den Präsidenten um finanzielle Unterstützung für diese Tätigkeit, da alle nichtamerikanischen Mittel durch die deutschen Siege weggebrochen seien. Clarence Pickett an Roosevelt 1/7/1940, in: AFSCA, AFSC Minutes 1940.

13 Unter den Deportierten befanden viele derjenigen, die das AFSC zuvor über die Pariser und Marseiller Hilfsstellen betreut hatte. Oftmals begleiteten die Helfer die Deportierten bis zu den Zügen, um den Angehörigen, die über die Hilfsstellen mit ihren Verwandten in Kontakt gestanden hatten lediglich die Nachricht übermitteln zu können: „adressee departed, destination unknown“, in: AFSC Annual Report 1942, 5-6. 
Zur selben Zeit eröffneten die Quäker ein Büro in Marseille im unbesetzten Teil Frankreichs, das in diesen Monaten zum Flaschenhals für Flüchtlinge aus ganz Europa wurde. Erst der amerikanische Kriegseintritt führte dazu, dass das AFSC alle verbliebene Arbeit (inklusive der Camps für die spanischen Flüchtlinge im Süden) an die einheimischen Glaubensgenossen des französischen Secours Quaker übergab; neun der Quäkerhelfer, die in Frankreich gearbeitet hatten, wurden für den Rest des Krieges als feindliche Ausländer in Baden-Baden interniert. $^{14}$

In Wien und Berlin, wo die Arbeit nach Kriegsbeginn ebenfalls auf niedrigerem Niveau fortgesetzt worden war, schlossen sich zur selben Zeit die Tore. In der deutschen Hauptstadt hatte im Juli 1940 Leonard Kenworthy, ein 28-jähriger Quäker aus dem Mittleren Westen, die Leitung des Quäkerzentrums von Howard Elkinton übernommen. Mit Kenworthys Abreise aus Berlin im Juni des darauffolgenden Jahres endete die seit 1920 bestehende Präsenz des AFSC in Deutschland und die Führung des Zentrums ging an die deutschen Quäker über. Noch während der letzten Monate seiner Amtszeit hatte Kenworthy gemeinsam mit einem kleinen Kreis deutscher Mitstreiter trotz großer Gefahr und vieler Verhaftungen weiter versucht, Menschen außer Landes zu bringen. Nach der Übergabe führten die deutschen Quäker das Zentrum aus Selbstschutz als nominell rein religiöses Unternehmen weiter, während sie einigen Verfolgten privat weiter Schutz und Hilfe boten. ${ }^{15}$

Auch in Wien ging die Arbeit noch für einige Zeit weiter. Hierhin entsandte das AFSC nach Kriegsbeginn Margaret Jones, um Käthe Neumayer, eine Katholikin, die das dortige Zentrum faktisch seit der Abreise der Briten geleitet hatte, in ihrer Arbeit zu unterstützen. Anders als in Berlin war das Wiener Zentrum in den vorangegangenen Jahren rein auf die Flucht- und Ausreisehilfe konzentriert gewesen. Religiöse Aspekte spielten hier keine Rolle mehr, auch weil die österreichischen Quäker sich überwiegend dem Nationalsozialismus angenähert hatten (und keine „Nicht-Arier“ in ihren Reihen akzeptierten). Als das AFSC sich im Juli 1941 endgültig zurückzog und die Verantwortung auch in Wien an die nun ge-

14 AFSC Annual Report 1943, 6.

15 Schmitt, Quakers and Nazis: Inner Light in Outer Darkness, 177-184. Über sein Jahr in Deutschland, das „herausforderndste Jahr meines Lebens“, hat Kenworthy einen eindringlichen Erfahrungsbericht hinterlassen. Leonard S. Kenworthy, An American Quaker inside Nazi Germany: Another Dimension of the Holocaust (Kennett Square, PA: Quaker Publications, 1982). Auf deutsch: Leonard Kenworthy, Ein Amerikanischer Quäker in Nazi-Deutschland: Das Schicksal der „Juden“ als tägliche Erfahrung 1940-1941 (Bad Pyrmont: Religiöse Gemeinschaft der Freunde 1984). 
samtdeutschen Quäker fiel, endete ein weiteres Kapitel der Flüchtlingshilfe des AFSC. ${ }^{16}$

Ein Teil dieser Hilfe verlagerte sich zur selben Zeit ins neutrale Portugal, das nun nach Marseille zum neuen Knotenpunkt der Flucht aus Europa wurde. Bereits Mitte 1941 eröffnete das AFSC in Lissabon ein Büro für Auswanderungsfragen mit zwei erfahrenen Leitern. Dieses diente Seite an Seite mit anderen Organisationen wie den Unitariern oder dem JDC als Anlaufstelle für die wachsende Zahl der Verzweifelten, die dort auf die Gelegenheit zur Atlantikpassage warteten. Hinter seiner Arbeit stand laut einem Bericht des AFSC eine Fülle von „human stories of missed boats and canceled visas, of lost baggage and the cumultative tragedy of those who flee war and persecution“. ${ }^{17}$ Das Büro der Quäker wurde in den folgenden Jahren zur Schleuse, durch die Tausenden von Menschen die Flucht gelang.

\section{Vom „Fanatismus des Guten“ im Krieg. Das AFSC zurück an der Heimatfront 1941-1945}

Mit der sukzessiven Abwicklung der internationalen Arbeit des AFSC in Berlin, Wien und Paris kam die Flüchtlingshilfe folglich nicht an ihr Ende. Im Gegenteil: Je mehr sich die Korridore der Flucht aus Europa verengten, desto intensiver und vielfältiger wurden die Bemühungen, auch und nicht zuletzt im eigenen Land. Damit wurde die Flüchtlingsarbeit in den USA zu einer tragenden Säule der Tätigkeit des AFSC während des Krieges. Die Refugee Section des AFSC, in die 1939 auch das Spanienkomitee eingegliedert worden war, koordinierte die verbliebenen Außenposten, von Lissabon über Mexiko-City, Santo Domingo und Rom bis nach Shanghai. Gleichzeitig half es denjenigen, denen es aller Widrigkeiten zum Trotz in diesen Jahren gelang, die USA zu erreichen.

Wie zuvor kümmerte sich das AFSC innerhalb des Netzwerks der Flüchtlingshilfe-Organisationen in erster Linie um die Bedürftigen, die aus dem Raster anderer Hilfsagenturen wie dem JDC herausfielen; Konfessionslose etwa oder „Non-Aryan Christians“. Das AFSC legte großen Wert darauf, die Quäkergemeinden im ganzen Land in seine Arbeit einzubeziehen, es verschaffte Tausenden die von den Einwanderungsbehörden geforderten Bürgschaften und finanzierte Schiffspassagen und vorübergehende Unterkünfte für die Neuankömmlinge. Das

16 Sheila Spielhofer, Stemming the Dark Tide: Quakers in Vienna 1919-1942 (York: William Sessions, 2001), $140-161$.

17 AFSC Annual Report 1941, 10. 
AFSC richtete daneben einen placement service ein, der Arbeits- und Ausbildungsstellen sowie Stipendien für jüngere Flüchtlinge vermittelte. Ein besonderes Gewicht lag auf Akademikern, wobei auch die vom Peace Service im Rahmen der International Institutes aufgebauten Verbindungen zu Colleges im ganzen Land zum Tragen kamen. ${ }^{18}$ Ergänzt wurde dieser Dienst durch das bereits erwähnte Scattergood Hostel in Iowa und eine Reihe ähnlicher Einrichtungen, in denen nach dem Prinzip der „Hilfe zur Selbsthilfe“ Crashkurse in englischer Sprache und für bestimmte handwerkliche Fähigkeiten für wechselnde Gruppen von neuangekommenen Einwanderern angeboten wurden. ${ }^{19}$

Die Refugee Section des AFSC kämpfte mit diesen Aktivitäten wie bereits während der 1930er Jahre an zwei Fronten gleichzeitig. Neben der Organisation der Flucht und der Integration der Neuangekommenen galt es auch immer Ressentiments $\mathrm{zu}$ begegnen, die den Flüchtlingen entgegenschlugen. Gerade in der Phase der amerikanischen Neutralität verschärfte sich die Stimmung noch einmal deutlich, getrieben nicht zuletzt von der xenophoben Rhetorik der isolationistischen America First-Bewegung. „More agression“ forderte auch deshalb Mary Rogers, die Vorsitzende der Refugee Section, 1941 von ihren Kollegen vom AFSC. Alttestamentarische Kräfte walteten nun erneut in der Welt, so Rogers, und das Böse in der Welt zu besiegen, erfordere von den Quäkern den Einsatz von ,equal force and drive and compulsion“, ein Aufgebot aller positiven Kräfte, kurz: einen „fanaticism of good“.20

Es gehe darum, so Rogers, den Neuankömmlingen durch das Beispiel jedes Einzelnen zu zeigen, dass die USA eine Demokratie seien, ,and that in spite of all the difficulties placed in their way, once within this country they will find refuge and protection. (...) If we truly believe in that spark of divinity in each man and truly believe that our strength and our greatness as a nation lies in our very diverse origins, we must go forth to proclaim these beliefs as convincingly as those who preach intolerance and hatred.“21

Auch vor diesem Hintergrund verlor die Flüchtlingsarbeit trotz der sinkenden Zahl derjenigen, die während des Krieges die USA erreichten, nichts von ihrem Gewicht: Wie es in einem Memorandum von 1943 hieß, erfüllten die Quäker mit ihr

18 Für den breiteren Kontext dieser Form der Hilfe und ihre länger zurückreichende Geschichte siehe auch Isabella.Löhr, „Solidarity and the Academic Community: The Support Networks for Refugee Scholars in the 1930s“, in: Journal of Modern European History 12, no. 2 (2014): 231- 46. 19 Andere solche Einrichtungen gab es im Bundesstaat New York oder auch auf Kuba für Flüchtlinge, die dort auf die Einreise in die USA warteten. Kathleen Hambly Hanstein, „Refugee Services of the American Friends Service Committee: An (Sic) Historical Summary“, (AFSC, 1967), 7. 20 Report of the Work of the Refugee Committee 1941, in: AFSCA, AFSC Minutes 1941. 21 Report of the Work of the Refugee Committee 1941, in: AFSCA, AFSC Minutes 1941. 
eine Verpflichtung, die sie 1938 mit ihrer Mission nach Deutschland eingegangen waren. Den eigenen Beitrag betrachteten sie dabei als einzigartig im Spektrum der Flüchtlingshilfe: Menschen, die sich hilfesuchend an die Quäker wandten, wüssten um deren „disinterested service“, dessen Qualität im „character of those who serve“ gründe. Die Adressaten der Hilfe spürten, dass „we have no ,ism“ to propound, no relief grant to refuse, no pressure to exert“. Bei allem verfolgten Quäker einen spezifisch auf das Individuum gerichteten Ansatz, „that at its best expresses itself in a distinctive quality of service. It is measured not in numbers nor in spectacular achievements, but in quiet understanding of suffering and need.“ Dies bedeute gleichzeitig, „that we perform a service not accomplished through other agencies“.22

Während die Flüchtlingsarbeit neue Aufgaben mit sich brachte, schloss das AFSC auf anderen Feldern an die Erfahrungen des Ersten Weltkriegs an. So wurde die Hilfe für Kriegsdienstverweigerer auch im Zweiten Weltkrieg zu einem zentralen Tätigkeitsbereich des AFSC im eigenen Land. Überlegungen, welche Form ein Ersatzdienst annehmen könnte, begannen schon früh: „To what extent can AFSC help provide pacifist service in peace-time and war-time“, lautete eine der Fragen, die Clarence Pickett dem Komitee Anfang 1940 zur Diskussion vorlegte. Im Idealfall solle das Komitee bereits zu diesem Zeitpunkt Ideen für einen Dienst entwickeln, „which might be looked upon by the government as alternative“, sobald der Kriegsfall eintrete. Dieser Dienst sollte vor allem sinnvoll („meaningful“) sein und zwar in einem zweifachen Sinn: „in the thing accomplished and in its effect upon the partaking group“ ${ }^{23}$

Bald schon wurden die Planungen konkreter. Bereits ein Jahr vor dem amerikanischen Kriegseintritt verabschiedete der amerikanische Kongress ein Einberufungsgesetz, das auch eine Regelung für Kriegsdienstverweigerer enthielt. Ihnen wurde ein alternativer Dienst in ,work of national importance“ in Aussicht gestellt. Anders als im Ersten Weltkrieg erstreckten sich die Bestimmungen nicht mehr allein auf die historical peace churches, sondern schlossen prinzipiell alle ein, die den Dienst an der Waffe aus „glaubhaften“ religiösen Gründen verweigerten. ${ }^{24}$ Bereits vor Verabschiedung des Gesetzes waren Clarence Pickett und Rufus Jones in die Verhandlungen zum Aufbau eines alternativen Dienstes in eigens dafür zu errichtenden Civilian Public Service Camps, einbezogen gewesen. Nach Kriegsbeginn übernahm das AFSC dann die Verwaltung von insgesamt 20

22 Sitzung des AFSC Board of Directors 18/3/1943, in: AFSCA, AFSC Minutes 1943.

23 Bericht von Clarence Pickett für das Jahr 1939, 26/1/1940, in: AFSCA, AFSC Minutes 1940. 24 General Meeting 23/1/1942, in: AFSCA, AFSC Minutes 1942. 
dieser Camps, in denen in der Regel nur eine Minderheit Quäker war. ${ }^{25}$ Die Tätigkeiten variierten von Aufforstungsmaßnahmen über Infrastrukturarbeiten bis hin zur Arbeit in Heil- und Pflegeanstalten. Einige Quäker stellten sich als „menschliche Versuchskaninchen“ zur Erprobung neuer Behandlungen gegen Kinderlähmung oder Typhus oder für Experimente zur Verfügung, die den Effekt von Unterernährung oder Unterkühlung auf den menschlichen Körper untersuchten. ${ }^{26}$

Wenngleich das AFSC die neuen Regeln und die Camps als Fortschritte gegenüber dem Ersten Weltkrieg begrüßte, blieben Wünsche offen - und zwar nicht nur weil die Kosten zum Unterhalt der Camps von den beteiligten Kirchen selbst getragen werden mussten. Schwerer wog aus Sicht der Quäker, dass der Civilian Public Service (CPS) den Spielraum für jene Art des constructive service einschränkte, der nach 1917 zum Markenzeichen des AFSC geworden war und der die Rolle des AFSC als einigende Kraft innerhalb der Society of Friends gefestigt hatte. Anfänglich hatten sich mit dem CPS als einem ,experiment of Church and State in the handling of conscentious objectors to war“27 noch große Hoffnungen verbunden. Das AFSC wollte als Kanal dienen, „through which persons of good will are able to expend their energies in some constructive, socially valuable work“. Durch die Art des Dienstes wollte man einmal mehr beweisen, „that we are unwilling simply to ,do time“ or to take a quiet place hidden from sight during the war““ ${ }^{28}$ Es sollte sich allerdings zeigen, dass der CPS von der Regierung im Gegenteil als ein Mittel gesehen wurde, um eine klare inhaltliche und räumliche Trennung zwischen Militär- und alternativem Zivildienst herzustellen. Von Anfang an existierten hohe Hürden für einen Dienst in Sanitäts- oder Wiederaufbaueinheiten nach dem Vorbild der angloamerikanischen Einheiten der Quäker im Ersten Weltkrieg. Weitverbreitete Vorbehalte gegen Kriegsdienstverweigerer führten schließlich dazu, dass der Kongress das Einberufungsgesetz durch einen Passus ergänzte, der den Einsatz im Ausland explizit ausschloss.

Als Clarence Pickett gegen Ende des Krieges dem Kongress und dem Präsidenten Bericht über die Aktivitäten der Quäker in den vorangegangenen Jahren

25 Etwa 10.000 Männer durchliefen die von den Quäkern verwalteten Camps, von denen rund ein Viertel der Society of Friends angehörte. Barnes, A Centennial History of the American Friends Service Committee, 128; 137.

26 Eine vollständige Liste der Versuche und der beteiligten Personen findet sich als Teil der Swarthmore Peace Collection als Human Guinea Pigs in CPS Detached Service, 1943-1946 (compiled by Anne M. Yoder), in: http://www.swarthmore.edu/Library/peace/////////conscientiousobjection/CPSResources/MEDICAL\%20RESEARCH.pdf (abgerufen 29.09.2021).

27 AFSC Annual Report 1942, 21.

28 A Summary of Activities, (wahrscheinlich Anfang) 1942, in: AFSCA, AFSC Minutes 1942. 
erstattete, war die Frustration über diese Entscheidung noch immer präsent. Ziel des AFSC sei wie 1917 gewesen, ,to render constructive national service through which it could promote human welfare, foster tolerance and goodwill and contribute to the building of a free and peaceful world society“. Bei aller Unterstützung des CPS seien dessen „inadequacies“ in dieser Hinsicht jedoch unübersehbar. Pickett monierte insbesondere den „wasteful use“ der Gewissensverweigerer, von denen viele Arbeiten verrichteten, ,which did not affect the wartime social emergencies of the nation“. Zur selben Zeit habe das AFSC Hilfsgesuche aus China, Indien, England und Frankreich ablehnen müssen, ungeachtet dessen, dass viele der Männer in den CPS-Camps über eben jene Fähigkeiten und Qualifikationen verfügten, die dort am dringendsten benötigt wurden. „Knowledge of the desperate suffering of people who have borne the brunt of war first-hand, suffering which must be alleviated now if at all“, schrieb Pickett, „,burdens our hearts and raises a compelling question in our minds as we contemplate the type of jobs which many of the CPS men are required to perform in our camps. ${ }^{\text {" } 29}$ In anderen Worten: Das AFSC hatte wie 1917 bereitgestanden, constructive service zu leisten, der dem Dienst an der Front in Bedeutung und Gefahr in nichts nachstand, während es der Regierung in erster Linie darum gegangen war, die Gewissensverweigerer der öffentlichen Aufmerksamkeit $\mathrm{zu}$ entziehen und sie damit unsichtbar werden $\mathrm{zu}$ lassen. ${ }^{30}$

Eine Gelegenheit zu constructive service ganz anderer Art eröffnete sich nach Kriegseintritt der USA dagegen durch die Politik der Regierung gegenüber Menschen japanischer Herkunft, von denen rund 110.000 von der Westküste in Internierungslager im Landesinneren zwangsumgesiedelt wurden. In seinem Einsatz für diese Gruppe, innerhalb derer viele die amerikanische Staatsbürgerschaft besaßen und die nun pauschal als „Sicherheitsrisiko“ gebrandmarkt und ausgegrenzt wurde, knüpfte das AFSC vielfach an die peace und interracial reconciliation work der Vorkriegszeit an. ${ }^{31}$ Die Aktivitäten des AFSC zielten nach 1941 darauf, das Los einer Gruppe zu verbessern, deren Behandlung in Picketts Worten „ha(s) revealed in the bloodstream of our American life a poison which has caused this disease of hatred“. ${ }^{32}$ Vertreter des AFSC begleiteten die Deportierten und

29 An Accounting to Congress and the President from the AFSC of the Religious Society of Friends in America on the Civilian Public Service, in: AFSCA, AFSC Minutes 1945.

30 Chuck Fager (Hg.), Friends in Civilian Public Service: Quaker Conscientious Objectors in World War II. Look Back and Look Ahead (Wallingford, PA: Pendle Hill Press, 1998).

31 Clarence Pickett definierte die Arbeit als Mittel ,in breaking the force of this calamity which has come upon the Japanese Population“, AFSC website, ARCHIVE HIGHLIGHTS: JapaneseAmerican Internment | American Friends Service Committee (afsc.org, abgerufen 21.06. 2021). 32 Zitiert nach Barnes, A Centennial History of the American Friends Service Committee, 130. 
halfen in den Lagern, bemühten sich um College-Stipendien für junge Amerikaner japanischer Herkunft und um Arbeitsplätze für Ältere, die so der Internierung entgehen konnten, und richteten Hostels als vorübergehende Bleibe für jene ein, die aus den Camps entlassen wurden. ${ }^{33}$ Daneben beteiligte sich das AFSC am juristischen Feldzug gegen die Internierungsmaßnahmen. So unterstützte das AFSC Gordon Hirabayashi, einen japanisch-amerikanischen Quäker aus Seattle, der die Rechtmäßigkeit der Maßnahmen in einem weithin beachteten Modellfall vor dem Obersten Gerichtshof anfocht - am Ende ohne Erfolg. ${ }^{34}$

Der Einsatz für die japanischen Amerikaner in den relocation camps und darüber hinaus war einer der Faktoren, durch den sich die Arbeit des AFSC an der „Heimatfront“ des Zweiten Weltkriegs von jener im Ersten Weltkrieg unterschied. Gleichzeitig trug das Komitee durchaus zur humanitären Mobilisierung der Kriegsgesellschaft bei. Rein quantitativ und in seiner Reichweite war der Beitrag des AFSC sogar noch weitaus umfangreicher als nach 1917. Große Bedeutung erlangte vor allem das Clothing Committee des AFSC, das ein breites Netz von lokalen Gruppen im ganzen Land organisierte, die tonnenweise Kleidung für Notleidende, Flüchtlinge und Kriegsopfer sammelten, aufbereiteten und nach Frankreich, China, Nordafrika und andere Orte verschickten. Auf mindestens zwei Feldern markierte die Arbeit des Clothing Committee auf anschauliche Weise die Entwicklung und den Wandel des AFSC seit dessen Gründung.

Zum einen stand diese Tätigkeit sinnbildlich für die enge Verbindung zwischen heimischer und auswärtiger Arbeit des AFSC. Ihre Wurzeln lagen in den Kleiderkollekten, die das Komitee erstmals für die notleidenden Bergarbeiter West-Virginias und Pennsylvanias zu Anfang der 1930er Jahre durchgeführt hatte, während der frühen New Deal-Jahre. Erst nach Kriegsbeginn verlagerte sich der Schwerpunkt zunehmend auf Europa, namentlich Frankreich und andere Zentren der Flucht wie Nordafrika und China, ohne dass die Hilfe im eigenen Land jemals ihre Bedeutung eingebüßt hätte. Sie blieb vielmehr - neben den homesteads - ein fester Bestandteil im Repertoire des AFSC in der Arbeit zu Hause. Folgerichtig wurden auch die japanisch-amerikanischen relocation camps in das Programm aufgenommen.

Zum anderen wurde diese Arbeit anders als im Ersten Weltkrieg nach den Prämissen des AFSC durchgeführt. Hatte sich die Tätigkeit der sewing clubs nach 1917 noch in das Netz der alles überspannenden Rotkreuz-Arbeit eingefügt, so war es nun das AFSC, das seinerseits über die Clothing Committees eine organisato-

33 Allan W. Austin, From Concentration Camp to Campus: Japanese American Students and World War II (Urbana, IL: University of Illinois Press, 2004).

34 Austin, From Concentration Camp to Campus. 
rische Plattform bot, an die sich andere Gruppen wie Mennoniten und Brethren, aber auch jüdische Gruppen, christliche Frauenvereine und viele weitere anschlossen. ${ }^{35}$ Die Berichte der Kriegsjahre fügen sich zu einem Bild umfangreicher Mobilisierung: „The work of clothing relief is made possible through the donations of several thousand people of good will, Friends, and others“, hieß es etwa in einem Bericht von 1940: „Some people knit or sew at home, others meet in groups under the auspices of Friends Meetings, churches or clubs, others work in independent groups. Some collect second-hand clothing and shoes. Some contribute money to purchase materials and clothing and to help defray freight charges.“36

Die Quäker stärkten so ihre Stellung auf doppelte Weise: Durch die Kleiderspenden wurde das AFSC an den Zielorten einmal mehr zum Gesicht amerikanischer Wohltätigkeit. Zur selben Zeit half diese Tätigkeit wie keine zweite, seine Position als integraler und dennoch klar profilierter Teil der Kriegsgesellschaft in den USA zu festigen, der Zehntausende von Amerikanern mit der Zivilbevölkerung in den verbündeten Staaten verband.

\section{Quäkerhilfe im Krieg}

Ein ähnliches Bild ergibt sich mit Blick auf die Hilfstätigkeit des AFSC außerhalb der USA. Auch hier zeigte das Komitee eine Mischung aus Annäherung und Abgrenzung gegenüber staatlicher Politik. Kritik an der Regierung konzentrierte sich anfänglich insbesondere auf die alliierte Blockadepolitik gegenüber den Achsenmächten, insofern diese die Zivilbevölkerung in den von Deutschland und Italien besetzten Gebieten betraf. Polen war der erste Fall gewesen, in dem eine Hilfsaktion gescheitert war. Nach dem deutschen Vormarsch in West- und Nordeuropa im Frühjahr 1940 entzündete sich in den USA eine weitere Diskussion an der Frage, ob Hilfe für die Zivilbevölkerung ein moralisches Gebot sei, oder ob sie, wie die Kritiker anmahnten, am Ende der deutschen Militärmaschinerie zu Gute kommen würde.

35 „The clothing, bedding, toys, soap, shoes and other gifts were contributed by many sewing groups - Friends, Church of the Brethren, and all the familiar Protestant sects, Jewish groups, Women's clubs, school and college groups, the YWCA Girl Reserves, 4H Clubs, social groups - and thousands of individuals. Money to purchase clothing was contributed by individuals and by the French Committees in the United States“, hieß es im Jahresbericht von 1943, AFSC Annual Report 1943, 10.

36 AFSC Annual Report 1940, 15. 
Das AFSC befand sich auf der Seite derjenigen, die, angeführt von Herbert Hoover und repräsentiert vom 1940 gegründeten Committee on Food for the Small Democracies, sich vehement für eine solche Hilfe stark machten. Gegen sie standen sowohl die US-Regierung als auch ein beträchtlicher Teil der Öffentlichkeit, die ganz im Sinn der britischen und der europäischen Exilregierungen Hilfsmassnahmen ablehnten. ${ }^{37}$ „What is the task of the AFSC in the present increasing need for relief in Europe as the possibility for sending supplies decrease?“, lautete die Frage in einem Memorandum, das Anfang 1942 im AFSC diskutiert wurde. Robert Yarnall war einer derjenigen, die dafür plädierten, mit dem „discontent to our own Government“ mit Bezug auf die Blockadepolitik nicht länger hinter dem Berg zu halten. Die Zeit sei vielmehr reif „,to speak out“. Gerade mit Blick auf die politische Aufladung der Frage in den USA seien es die Quäker „as a neutral body free from politics (who) could best press this concern“. Das AFSC war sich zur selben Zeit bewusst, dass eine Änderung der Politik ebenso wenig zu erwarten war wie eine entscheidende Wendung in der öffentlichen Meinung. Vielmehr müsse man sich darauf einstellen, dass die Anzahl der Menschen, „who say the Nazis will get the food“, eher noch wachsen werde. „The hope was expressed“, vermerkte das Protokoll, „that we should not hold back because we do not see definite steps ahead. Friends have always plunged forward and have worked miracles on faith." Einigkeit herrschte darüber, dass in dieser Frage kein Kompromiss möglich war. Das moralische Recht, so James Vail, sei auf der Seite der Quäker: „To starve children is evil and the consequences of breaking moral laws are sure. (...) our faith rests firmly on the moral arguments and not be led astray by using political reasons for righteousness. There is no argument that can stand against the fact that children ought to be fed. The whole tradition of the Society of Friends calls upon us to support this issue because it is right. " ${ }^{38}$ Dessen ungeachtet sollte sich der „psychological moment“, den Clarence Pickett für eine solche Aktion in der Zukunft kommen sah, als eine reine Illusion erweisen. An der

37 Curti, American Philanthropy Abroad, 433-435.

38 James Vail unterstützte dieses Argument: „The American public should be approached in a convincing way. Thousands of deaths have already occurred. We know out of our direct experience that the supplies which come into our hands are used as the donors have directed. There is every reason to suppose that we can continue our work.“ Clarence Pickett stimmte zu: „Time is ripe to make an effort in this food situation and it will take all the power that can be generated." Allerdings kam das AFSC aus Sicht Picketts für eine Verteilung in den besetzten Gebieten nicht in Frage. Das Internationale Rote Kreuz war deshalb angefragt worden, ob „it would administer in occupied territory, since, obviously, we would not administer in Occupied Territories“. Treffen des General Meeting - Fragen des AFSC 23/1/1942, in: AFSCA, AFSC Minutes 1942. 
Blockadepolitik der Alliierten war, moralische Argumente hin oder her, nicht zu rütteln. ${ }^{39}$

Spannungen wegen der neutralen Haltung des AFSC und in seinem Verhältnis zur offiziellen amerikanischen Außenpolitik zeigten sich zeitgleich an anderer Stelle. Am deutlichsten traten sie mit Blick auf China zu Tage. Spätestens seit dem Beginn des Japanisch-Chinesischen Krieges 1937 stand China im Fokus amerikanischer Hilfsaktivitäten, bei denen die geopolitischen Interessen der USA in Asien eine gewichtige Rolle spielten. Der Kriegsbeginn und die weitere Verschlechterung der amerikanisch-japanischen Beziehungen rückten die politische Dimension der Hilfe noch stärker ins Blickfeld. Als sich im Frühjahr eine Reihe von Hilfskomitees zum United China Relief zusammenschlossen, wurde dies von Stellungnahmen begleitet, die China als Bollwerk gegen den japanischen Machtanspruch, als „first line of American defense in the Pacific“ und „frontier of democracy in the far Pacific" beschrieben. ${ }^{40}$

Vor diesem Hintergrund stand auch hinter der Neutralität des chinesischen Engagements des AFSC von Anfang an ein Fragezeichen. Die Gründung eines auf China gerichteten Committee for the Orient und die Beteiligung an einem Quäkerzentrum in Shanghai Ende der 1930er Jahre waren zu einem guten Teil auf die wachsende Gruppe europäischer Flüchtlinge im international settlement der südchinesischen Metropole zurückzuführen. Bei diesem Engagement war das AFSC darauf bedacht, alles zu vermeiden, was als Parteinahme im chinesischjapanischen Konflikt verstanden werden könnte. Die Aussöhnung mit Japan, ein Schwerpunkt in der Arbeit des AFSC seit den 1920er Jahren, sollte auf keinen Fall durch die Aktivitäten in China in Frage gestellt werden wo das AFSC zudem, anders als andere protestantische Gemeinschaften in den USA auf keine nennenswerte missionarische Tradition zurückblickte. Als das AFSC nach längerem Zögern 1941 dem United China Relief beitrat, tat es dies unter der ausdrücklichen Prämisse, dass sich dieser in seinen Spendenkampagnen aller dezidiert anti-japanischen Töne enthalten würde. ${ }^{41}$ Eine Sitzung des AFSC Ende 1942, bei der Eugene Barnett vom UCR die Ziele der Organisation präsentierte, gab tiefe Ein-

39 Eine der Initiativen die aus dem erneuten Kampf gegen die Blockadepolitik und deren Folgen für die Zivilbevölkerung in den von den Achsenmächten besetzten Gebieten entstand war das Oxford Committee for Famine Relief (später: Oxfam) Es gründete sich 1942 unter prominenter Beteiligung britischer Quäker vor dem Hintergrund der Blockade des besetzten Griechenlands und der dadurch verschärften Hungersnot.

40 Curti, American Philanthropy Abroad, 424-425.

41 Clarence Pickett hatte sich in seinen Erinnerungen versichern lassen, ,that no ,hate Japan“ campaign was sanctioned“, Pickett, For more than Bread, zitiert nach Curti, American Philanthropy Abroad, 466. 
blicke in die Erwartungen und Bedenken, die hinsichtlich der Arbeit in China bestanden. Barnett, der selbst lange Jahre als internationaler Sekretär des YMCA in China gearbeitet hatte, ordnete die langfristig angelegte Arbeit des UCR vor dem Hintergrund amerikanischer Interessen in der Region ein. China sei, so Barnett, „our biggest single asset from any standpoint“, sowohl was die Zukunft der Christenheit als auch was demokratische Prinzipien in der Welt angehe. Es gelte nun die Grundlagen für die Nachkriegszeit zu legen und durch die Arbeit diejenigen zu stärken, die einen „American outlook“ teilten. In diesem Sinne sei die Arbeit der AFSC-Freiwilligen in China als „Agents of the American people“ mit jener vergleichbar, welche die Quäker in Europa nach dem Krieg geleistet hätten. ${ }^{42}$

Dieser Verantwortung gegenüber einem Land, mit dem, in Clarence Picketts Worten, „we must deal in the future, with which as a nation we will deal“, wollte sich das AFSC nicht verschließen. Bedenken bestanden vor allem hinsichtlich der Art des Dienstes und speziell hinsichtlich der Frage, „whether there is an opportunity that it is not tied in with the Chinese or American armies in such a way as cannot be approved“. ${ }^{43}$

Hier nahm Pickett insbesondere Bezug auf eine Anfrage britischer Quäker vom Februar 1941, sich einer in der britischen Kolonie Birma (dem heutigen Myanmar) tätigen Friends Ambulance Unit anzuschließen. Diese Einheit, die bald unter der Bezeichnung China Convoy einige Bekanntheit erlangen sollte, setzte sich aus britischen und kanadischen Gewissensverweigerern zusammen, die meisten unter ihnen Quäker. Die Aufgabe des China Convoy bestand darin, medizinische Versorgungsgüter über die gefährliche Burma Road durch die Berge nach West-China zu transportieren. An der militärischen Funktion des China Convoy konnte dabei kaum Zweifel bestehen, versorgte er doch sowohl Militär als auch Bevölkerung in einem Gebiet, das den Rückzugsraum der nationalchinesischen Regierung und Armee darstellte, die durch den japanischen Vormarsch von allen Seeversorgungswegen abgeschnitten waren. ${ }^{44}$ Nach der japanischen Besetzung Birmas im Frühjahr 1942 verlagerte sich die Arbeit des Konvois, der vom kanadischen Arzt Robert McClure geleitet wurde, ganz nach China. Er verfügte über eine Reihe von Krankenwagen und zwei mobile Kliniken. Seine Hauptfunktion bestand dennoch hauptsächlich im Transport; mit seinen rund 50 Lastwagen leistete er einen gehörigen Beitrag zur Versorgung der west-chinesischen Provinzen. ${ }^{45}$

42 Sitzung des Executive Board 3/11/1942, in AFSCA, Minutes 1942.

43 Sitzung des Executive Board 3/11/1942, in AFSCA, Minutes 1942.

44 Susan Armstrong-Reid, The China Gadabouts: New Frontiers of Humanitarian Nursing, 1941-51 (Vancouver: UBC Press, 2018).

45 Armstrong-Reid, The China Gadabouts. 
Wenngleich sich zu Beginn der amerikanischen Beteiligung am China Convoy weder die USA noch Großbritannien im offiziellen Kriegszustand mit Japan befanden, stellte die Teilnahme das AFSC vor ein Dilemma. Fraglos handelte es sich um einen Einsatz, der das Komitee gefährlich nah an eine direkte Parteinahme im Krieg führte. Dies war der Hintergrund der oben zitierten kontrovers geführten Debatte im AFSC Ende 1942, bei der es auch um die Eingliederung der Arbeit des China Convoy in den größeren Kontext der Hilfe des UCR in China ging. Die Frage vieler Teilnehmer lautete, ob sich eine solche Arbeit nicht unabhängig von ihrer humanitären Ausrichtung schlicht in den amerikanischen Kriegsaufwand einordne. Anders betrachtet sahen einige keine Grundlage für einen quäkerspezifischen Dienst: „We have never felt we were a general relief agency“, bemerkte etwa Bernard Walton. Den Ruf 1920 nach Deutschland zu gehen, habe man angenommen, ,because the tensions were such that a general agency would not have been welcome“. Waren die Spannungen in China von der gleichen Art, „is China within such limitations“? Walton zweifelte wie viele andere daran. Der vorrangige Konflikt in der Gegenwart bestand wie auch Clarence Pickett eingestand zwischen Japan und China, und zu dessen Beilegung würde eine Beteiligung der Quäker nichts beitragen. ${ }^{46}$

Bedenken gab es auch, was die konkret geplante Zusammenarbeit mit den Briten im China Convoy betraf. Ein vertraulicher Bericht des AFSC hatte die Arbeit der Einheit im Sommer 1942 zwar in den höchsten Tönen gelobt, gleichzeitig jedoch die starken Vorbehalte amerikanischer Offizieller vor Ort gegen eine Beteiligung der USA herausgestrichen. Der China Convoy gelte weithin als britisches Propagandainstrument. „In view of the propaganda value of relief operations“ und angesichts der Tatsache, dass es sich bei China um ureigenstes Interessengebiet der USA handele, spreche sich etwa der amerikanische Botschafter in Chungking entschieden gegen eine amerikanische Finanzierung des China Convoy aus, solange dieser seinen britischen Charakter aufrechterhalte. ${ }^{47}$ Auch Befürworter des Unternehmens, die - wie der ehemalige Vorsitzende des Spanienkomitees John Rich $^{48}$ - gerade in Hinblick auf eine Stärkung des quäkerspezifischen

46 Eugene Barnett verwies darauf, dass sich Probleme dieser Art mit Kriegsende notwendigerweise einstellen würden und dass sie Raum für Versöhnungsarbeit bieten würden. Die Kommunisten seien im Untergrund und warteten auf ihre Chance. „I rather tremble privately as to what will happen with in China when the common peril of invading foe removed. If Friends want trouble, you will find plenty of it.“ Es werde viele Spannungen geben, wenn der Krieg vorbei ist. Wenn man dagegen etwas tun wolle, sei jetzt die Zeit, um dort zu sein. Sitzung des Executive Board 3/11/1942, in: AFSCA, Minutes 1942.

47 Sitzung des Executive Board 3/11/1942, in AFSCA, Minutes 1942.

48 John Reich hatte seinen Namen 1939 in John Rich geändert. 
Profils der eigenen Hilfstätigkeit die Chancen einer angloamerikanischen Zusammenarbeit für das AFSC unterstrichen, mussten konzedieren, dass die britische Dominanz schwierige Fragen aufwarf. ${ }^{49}$

Warum man sich dennoch für eine Zusammenarbeit entschied und dies auch später niemals ernsthaft in Frage gestellt wurde, darüber geben womöglich am besten die Versuche des AFSC Auskunft, den China Convoy als einen möglichen Einsatzort für die Mitglieder des Civilian Public Service ins Spiel zu bringen. Offensichtlich handelte es sich in den Augen des AFSC um jene Art des constructive service, der im Ersten Weltkrieg von den Wiederaufbau- und Sanitätseinheiten geleistet worden war. Er brachte die Teilnehmer nahe ans Frontgeschehen und war vergleichbar mit dem Dienst an der Waffe - der Einsatz war genauso gefährlich und forderte eine ähnlich hohe Opferbereitschaft der Rekruten. Entsprechend groß war die Ernüchterung, als das Veto des Kongresses 1943 dem Einsatz von CPS-Männern im Ausland einen Riegel vorschob. Auch die Versuche, eine Ausnahmegenehmigung für 70 Mann zu erhalten, scheiterten. ${ }^{50}$ Auf diese Weise blieb der Dienst für Amerikaner bis Ende des Krieges auf diejenigen begrenzt, die nicht vom draft erfasst waren. Auch ohne Gewissensverweigerer erlangte der China Convoy im Nachhinein auch in den USA quasi-mythischen Status, nicht zuletzt da er als Nachweis der äußersten Opferbereitschaft der Quäker galt und dem Ruf des Drückebergertums entgegenwirkte, der die Quäker auch im Zweiten Weltkrieg verfolgte..$^{51}$ Über die Beteiligung des AFSC am China Convoy ergab sich vor dem Hintergrund der Hungersnot in Bengalen ab 1942 auch ein weiterer im Umfang kleinerer Einsatz, der britische und amerikanische Quäker zusammenführte..$^{52}$

49 Confidential Report Special Meeting of Board of Directors and joint Foreign Service Executive committee 23/7/1942, in: AFSCA, Minutes 1942.

50 Vor dem Entscheid des Kongresses hatte Pickett bereits erfolgreich die Erlaubnis des Präsidenten eingeholt, 70 CPS-Männer nach China zu schicken. Franklin D. Roosevelt an Clarence Pickett 13/2/1943, AFSCA, AFSC Minutes 1943.

511942 arbeiteten neben 70 Briten, zwei Kanadieren und acht Chinesen 16 US-Amerikaner im China Convoy. Diese Zahlen blieben auch in den kommenden Jahren stabil, der Anteil Einheimischer stieg jedoch beträchtlich (1944 waren es 16 Amerikaner und 69 Briten, aber 23 Chinesen) Die Berichte betonten den „Enthusiamus“ und die „understanding fellowship“ mit den chinesischen Partnern, die sich zu einer „expression oft he Christian spirit in a World at war“ summierten. Der Jahresbericht von 1942 gibt gleichzeitig einen guten Eindruck von dem heroischen Ton, der seinen Einsatz begleitetete: „Medical members of the Unit fight disease and death in mobile surgeries in areas of greatest need“. AFSC Annual Report 1942, 7-8. ; AFSC Annual Report $1944,11-12$.

52 Siehe dazu den jüngst erschienenen Aufsatz von Steven Baumann der die Bedeutung dieses Einsatzes für die Entwicklung eines längerfristigen Hilfsansatzes hervorhebt. Steven Patrick 
Zur selben Zeit versuchte das AFSC sich frühzeitig in Position zu bringen, um seiner Stimme in den offiziellen Planungen für die Nachkriegsordnung Gehör zu verschaffen. Diese Planungen hatten bereits unmittelbar nach dem amerikanischen Kriegseintritt Fahrt aufgenommen. „How can the AFSC influence public opinion toward constructive thinking on post-war reconstruction and relief ",53 lautete die Frage Anfang des Jahres 1942. Dieser Anspruch traf sich mit der Entschlossenheit der US-Regierung noch weitaus mehr als im Ersten Weltkrieg das volle Potenzial humanitärer Hilfe in einem militärischen und politisch-diplomatischen Sinn auszuschöpfen. Entsprechend früh bemühten sich Roosevelt und das State Department darum, die Aktivitäten privater Hilfsorganisationen einer strengen Kontrolle zu unterziehen. Seit dem Spanischen Bürgerkrieg verfügte die Regierung dabei über ein wirksames Instrument, denn amerikanische Hilfsorganisationen, die im Ausland tätig waren, mussten sich vom State Department lizensieren lassen. Nach dem Kriegseintritt wurde dieses Instrument, das im Sinne der Neutralitätsgesetzgebung eher defensiv ausgerichtet war, indem es eine Kompromittierung der Regierung durch private Hilfsaktivitäten im Ausland verhindern sollte, durch eine offensive Komponente ergänzt. Es ging nun darum, Private Voluntary Organizations (PVOs) auf die Regierungspolitik einzuschwören und zu einem aktiven Teil des Kriegsaufwandes zu machen. Die Einrichtung des War Relief Control Board im Juli 1942 durch den Präsidenten war ein erster Schritt, durch den zunächst eine Vereinheitlichung und eine „Amerikanisierung“ von PVOs erreicht werden sollte.

Als zweiter Schritt folgte wenig später die Gründung eines Office of Foreign Relief and Rehabilitation Operations (OFRRO) im State Department. Dies zeigte, dass man von einem steigenden Bedarf an humanitärer Hilfe in Folge alliierter Erfolge auf dem Kriegsschauplatz und in Folge der Befreiung besetzter Territorien ausging. Geleitet wurde das OFRRO vom Gouverneur New Yorks, Herbert Lehman, einem Vertrauten Roosevelts und alten Bekannten des AFSC seit der Zeit der russischen Hilfsaktion, als dieser für das JDC die Verhandlungen mit den Quäkern geführt hatte. ${ }^{54}$ Von der Einrichtung des OFRRO führte ein direkter Weg zur Gründung der United Nations Relief and Rehabilitation Administration (UNRRA) Ende 1943, die vor allem den Wunsch der USA nach einer kontrollierten Internationalisierung der Not- und Wiederaufbauhilfe ausdrückte. Es ging der Roosevelt-Regierung - auch mit Blick auf die Erfahrungen nach dem Ersten Weltkrieg - um amerikanische Kontrolle über den Wiederaufbau. Gleichzeitig wollte

Baumann, „Quaker Relief and Rehabilitation: The Bengal Famine 1942-1945.“ Quaker Studies 25, no. 1 (2020): $96-112$.

53 Treffen des General Meeting - Fragen des AFSC 23/1/1942, in: AFSCA, AFSC Minutes 1942. 54 Siehe Kapitel 4. 
die US-Regierung der Kritik der Alliierten an der amerikanischen Dominanz zuvorkommen und gleichzeitig einen Teil der Kosten auf die Verbündeten übertragen. An der zumindest anfänglichen US-Vormachtstellung innerhalb von UNRRA konnte kein Zweifel bestehen: Zwischen OFRRO und UNRRA bestanden vielfältige personelle Kontinuitäten; bester Ausdruck war der nahtlose Wechsel Herbert Lehmans von der Spitze des OFRRO auf die Position des UNRRA-Generaldirektors. $^{55}$

Bedeutend aus Sicht des AFSC war, dass private Hilfsorganisationen in den Planungen sowohl des OFRRO als auch der UNRRA eine Schlüsselrolle einnahmen. Bereits aus seinen ersten Gesprächen mit Lehman im Sommer 1942 konnte Clarence Pickett die Gewissheit mitnehmen, dass die Fortführung der humanitären Arbeit der Quäker wie anderer PVOs unter dem Dach von OFRRO aus dessen Sicht essenziell war, „not only as an expression of the generous sympathies of the American people but also as a distinctive service that quasi-public and voluntary agencies can render to complement public resources and services“. Es gebe aus Lehmans Sicht „many essential services which can be provided by private agencies that cannot be provided by the government “. ${ }^{56}$

Umgekehrt stellte sich angesichts der Avancen von Seiten des OFRRO die Frage, inwiefern und zu welchen Bedingungen das AFSC bereit war, sich auf eine Zusammenarbeit unter Kriegsbedingungen einzulassen. Im Prinzip bestand Einigkeit darüber, dass die Quäker versuchen sollten, „(to) contribute whatever they can toward influencing in the right directions the policies, decisions and thinking which are now (...) taking shape in Washington“. Aus diesem Grund beschloss das AFSC Anfang 1943, eine Verbindungsperson in der Hauptstadt zu installieren, die unter anderem gegenüber dem State Department Einfluss bei der Behandlung von „problems of world order and future international relations“ ausüben sollte. ${ }^{57}$ Die Zusammenarbeit mit dem OFRRO begann früh im Jahr 1943 und folgte der alliierten Kampagne im französischen Nordafrika, das angloamerikanische Truppen im November des Vorjahres besetzt hatten. Die Quäker setzten im marokkanischen Casablanca und in Algiers im Wesentlichen ihre Arbeit für spanische

55 Jessica Reinisch, „Internationalism in Relief: The Birth (and Death) of Unnra“, in: Past and Present 210, Supplement 6 (2011); Ben Shephard, ,,Becoming Planning Minded‘: The Theory and Practice of Relief 1940 - 1945“, in: Journal of Contemporary History 43, 3 (2008).

56 A summary of activities 1942 ( wahrscheinlich Anfang 1943), in: AFSCA, AFSC Minutes 1943. 57 „Method to be employed (im Umgang mit SD-Leuten, DM) would not be one of pressure and protest, but rather, the quiet cultivation of friendly contacts and acquaintance and the utilization of conferences and discussion as opportunities for expressing views and ideas." Report of Committee of AFSC Board to explore Friends responsibility with reference to government policies, in: AFSCA, AFSC Minutes 1943. 
Flüchtlinge und für die Gruppe von europäischen Exilanten fort, die unter der Herrschaft der Vichy-Regierung interniert worden waren..$^{58}$

Verlief die Zusammenarbeit mit der Lehman-Behörde weitgehend reibungslos, so verschärfte der Übergang vom OFRRO zur UNRRA die Bedenken, ob die eigene Identität in der Zusammenarbeit gewahrt bleiben könnte. Private Voluntary Agencies sollten gemäß den Vorstellungen der UNRRA-Planer zwar grundsätzlich ihre organisatorische Integrität behalten. Darüber hinaus sollten diese sich jedoch den Weisungen der Organisation unterstellen, die den beteiligten PVOs Einsatzgebiete und Ressourcen aus einem von allen beteiligten Organisationen gebildeten Pool zuteilen würde. Das schürte Ängste im AFSC. Anfang 1944 gab ein Memorandum der Sorge Ausdruck, ,that if we are going to lose our identity in the mass, it will not be possible to do the type of work we desire and for which we are peculiarly fitted“. Ziel müsse deshalb sein, „to maintain our freedom and refrain from going into spectacular pieces of work if it means ,losing our soul““. 59

Ein weiteres Problem stellte die unmittelbare Verbindung der UNRRA zum alliierten Militärapparat dar. Der Auftrag der UNRRA schrieb vor, dass sich die Agentur im Kielwasser des militärischen Vormarsches bewegte. Deutlich wurde dies etwa, als die UNRRA Ende 1943 Einladungen an 500 künftige Mitarbeiter der beteiligten PVOs bezüglich der Ausbildung in Ägypten verschickte, die dort auf den Hilfseinsatz auf dem Balkan vorbereitet werden sollten. Das AFSC, das 15 Männer entsandte, sorgte sich, diese könnten für einen Dienst vorbereitet werden, „which might seem to be a part of military services“ “.0 Unter diesen Umständen hatte das AFSC, wie bemängelt wurde, kaum mehr Einfluss auf die Ausbildung, zumal auch für die UNRRA keine Gewissensverweigerer aus den CPS-Camps verwendet werden konnten. ${ }^{61}$ Vor diesem Hintergrund ging es darum, dort zu arbeiten, „where we can make the greatest contributions in terms of spiritual values, not necessarily the largest operations “ ${ }^{62}$ Im Allgemeinen wurde die „double loyalty“, die die Tätigkeit unter der UNRRA mit sich brachte, als problematisch empfunden. Insgesamt galt deshalb für die Zusammenarbeit die Devise: „as far as conscience allows“. ${ }^{63}$

Deshalb legte das AFSC auch keinen Wert auf einen Einsatz in der Nähe der Front und beteiligte sich nur am Rande am Einsatz der UNRRA, der den alliierten

58 AFSC Annual Report 1943, 7.

59 Minutes Board of Directors 1/1944, in: AFSCA, AFSC Minutes 1944.

60 Treffen des Board of Directors 4/11/1943, in: AFSCA, AFSC Minutes 1943.

61 Die Beziehungen zum OFRRO, Bericht über ein Gespräch mit Herbert Lehman 2/6/1943, in: AFSCA, AFSC Minutes 1943.

62 Treffen des Board of Directors, 7/7/1943, in: AFSCA, AFSC Minutes 1943.

63 Minutes Foreign Service Section 5/6/1944, in: AFSCA, AFSC Minutes 1944. 
Vormarsch in Italien und auf dem Balkan 1943 begleitete. Stattdessen blieben die Flüchtlingslager in Nordafrika eines der Haupteinsatzgebiete des AFSC. So übernahmen die Quäker im Auftrag der UNRRA in erster Linie die Betreuung von 30.000 jugoslawischen Flüchtlingen, die sich seit Anfang 1944 im Camp El Shatt auf der Sinaihalbinsel befanden. ${ }^{64}$

Zur selben Zeit reichten die Pläne über die laufenden Einsätze hinaus bereits weiter in die Zukunft. „This is a critical moment in our history“, gab Clarence Pickett 1943 den Ton der Debatte vor. ${ }^{65}$ Vieles werde anders sein in der Zeit nach dem Ende des Krieges, aber das AFSC stehe bereit, sich der Herausforderung zu stellen. Worum es dem AFSC ging, war, wie die Debatte zeigte, sich als Hilfsagentur mit einem eigenen Profil in allen Phasen des erwarteten humanitären Einsatzes nach dem Krieg in Stellung zu bringen: von der ersten Phase der unmittelbaren Nothilfe (emergency relief) über den Beginn des Wiederaufbaus (transition to reconstruction) bis zur letzten Phase des Wiederaufbaus in Zusammenarbeit mit den befreiten und besetzten Ländern (co-operative reconstruction). Das Gewicht der Überlegungen lag dabei eindeutig auf der letzten Phase. Hierfür hatte das AFSC präzise Vorstellungen, sowohl was den Bedarf als auch was die konkrete Umsetzung der Hilfe betraf, die sich zusammengenommen zu einem „New Deal for the World“66 mit spezifischem Quäkereinschlag summierten. ${ }^{67}$

Das quäkerspezifische Element bestand wie eingangs erwähnt nicht zuuletzt in der Spezialisierung auf bestimmte „unpopuläre“ Gruppen von Notleidenden. Im Blick hatte man neben der Zivilbevölkerung in den besiegten Ländern auch die Millionen sogenannter Displaced Persons (DPs), die etwa als Zwangsarbeiter insbesondere in den deutschen Herrschaftsbereich verschleppt worden waren und dort absehbarerweise bei Kriegsende eine riesige Herausforderung für die Besatzungsarmeen darstellen würden. Diesen beiden Gruppen sollte das Haupt-

64 Es handelte sich hier überwiegend um Flüchtlinge aus Dalmatien, die 1943 vor der deutschen Balkanoffensive auf die von der britischen Air Force gehaltene Adria-Insel Vis geflohen und die vom britischen Militär Anfang 1944 nach Ägypten evakuiert worden waren. Das Wüsten-Camp ElShatt existierte bis ins Jahr 1946, dem Zeitpunkt, an dem die meisten der Insassen nach Jugoslawien repatriiert worden waren. 22/9/1944, in: AFSCA, Foreign Service Section 1944.

65 Confidential Memorandum on post-war planning, Foreign Service Section 4 und 5/6/1943, in: AFSCA, AFSC Minutes 1943.

66 Elizabeth Borgwardt, A New Deal for the World: America's Vision for Human Rights (Cambridge, MA/London: Harvard University Press, 2005).

67 Confidential Memorandum on post-war planning, Foreign Service Section 4 und 5/6/1943, in: AFSCA, AFSC Minutes 1943. 
augenmerk gelten. ${ }^{68}$ Ebenso entscheidend wie das „Wer“ war freilich das „Wie“ der Hilfe.

Hier galt es die Lehren der Vergangenheit zu berücksichtigen. Die Erfahrung des New Deal etwa schärfte die Sinne für die Bedeutung der Wiederherstellung umfassender sozialer Sicherheit in den besetzten Gebieten. Nothilfe war wenngleich notwendig nur ein erster Schritt. Das AFSC plädierte nicht nur für den unverzüglichen Abbau von Blockaden gegenüber den besiegten Ländern, sondern auch für den raschen Wiederaufbau der Wohlfahrtseinrichtungen in enger Zusammenarbeit mit der lokalen Bevölkerung sowie für die Stabilisierung von Löhnen als Mittel zur Wahrung des gesellschaftlichen Friedens. Ziel musste in jedem Fall die Nutzung vorhandener Strukturen und die frühestmögliche Übergabe an Einheimische sein. ${ }^{69}$

Seine eigene Rolle sah das AFSC bei der Hilfe für eine Reihe von Gruppen, die aus unterschiedlichen Gründen seit längerem im Fokus der Quäkerhilfe standen und beim Wiederaufbau strategisches Gewicht besaßen. Dies waren neben Intellektuellen (aufgrund deren herausgehobener Position im „leadership building“), vor allem Jugendliche und junge Erwachsene (adolescents). Vor allem bei Letzteren, einer „forgotten group“ der Vergangenheit, wollte man ansetzen: Es handele sich um eine traumatisierte Generation, die gleichzeitig am offensten für einen kooperativen Ansatz und für spiritual rehabilitation sei. Ziel sei es, sie durch den Wiederaufbau von „hostile observers“ $\mathrm{zu}$ „more active observers“ und schließlich zu „active participants“ und Multiplikatoren zu machen. Gerade in Deutschland nach dem Ende der Nazi-Diktatur werde ein solcher Ansatz benötigt werden. Hier lag, so ein Teilnehmer der Debatte, ein Alleinstellungsmerkmal der Quäker, welche die Erziehung zur Demokratie um eine spirituelle Dimension erweitern könnten: „We don't want just to hit people over the head with Forget Nazism, Believe in Democracy. “ Was dem AFSC vorschwebte, war ein umfassendes Programm, bei dem Institutionen wie community houses eine herausgehobene Stellung haben würden. Unschwer erkennbar waren gerade in diesen Ideen die Erfahrungen des New Deal und insbesondere der homestead-Bewegung lebendig. Sie sollten im Nachkriegsdeutschland in vom AFSC initiierten Nachbarschaftsheimen wie dem Mittelhof in Berlin-Zehlendorf ein Echo finden. Daneben bestand weitgehende Einigkeit, dass die Versöhnungsbereitschaft Grenzen haben musste, sollte das Ziel eines demokratischen Deutschlands nicht von vornherein belastet werden: „We must think through an acceptable way of

68 Confidential Memorandum on post-war planning, Foreign Service Section 4 und 5/6/1943, in: AFSCA, AFSC Minutes 1943.

69 Confidential Memorandum on post-war planning, Foreign Service Section 4 und 5/6/1943, in: AFSCA, AFSC Minutes 1943. 
punishing those in the ex-enemy countries who have committed serious crimes which are crimes under any code for there must be some outlet for the hatred which exists."

Bei der Organisation der Nachkriegshilfe sah das AFSC seine Rolle gleichermaßen in Europa wie zu Hause. Aus der im Vergleich zu anderen Hilfsagenturen freieren Position der Quäker, „to make recommendations and to interpret what we might feel was a really social and really peaceful policy“, ergab sich auf beiden Ebenen Verantwortung: Gegenüber der Regierung und speziell gegenüber dem OFRRO bestehe die vorrangige Aufgabe, die Bereitschaft der Quäker zur Übernahme „unpopulärer“ Hilfe zu verdeutlichen. Aber auch gegenüber der Öffentlichkeit im eigenen Land gelte es frühzeitig ,to insert something into the interpretation of goals and methods of reconstruction so that other people will become aware of our goals as we see them“. Besonderes Gewicht hatte die Zusammenarbeit mit anderen Hilfsagenturen, auch und nicht zuletzt um eine Konkurrenz um Ressourcen zu vermeiden. „If we hope for joint services, we have to enter joint services and sometimes initiate them", hieß es dazu knapp im Protokoll. Clarence Pickett sollte in den folgenden Jahren in der Tat eine Schlüsselrolle bei der Gründung der inter-agency cooperation im Rahmen der UNRRA und später im Vorfeld der Gründung der Cooperative for American Remittances to Europe (CARE) übernehmen. ${ }^{70}$

Auch international wurde eine breite Einbindung angestrebt, die von den internationalen Organisationen wie dem Völkerbund, der UNRRA oder der ILO über den Weltstudentenbund bis hin zur internationalen Frauenbewegung reichten. ${ }^{71}$

Wie weit sich die Quäker in ihren Vorstellungen von den Hilfstätigkeiten der Vergangenheit entfernt hatten, wird deutlich mit Blick auf die Haltung, die das AFSC zur Frage einer eventuellen Kinderspeisungsaktion nach dem Vorbild Deutschlands und der Sowjetunion in den 1920er Jahren einnahm. Eine solche Idee wurde glatt verworfen, bei aller Popularität, die die Idee in der Öffentlichkeit genieße. Vielmehr bestehe die Aufgabe darin, „to educate the public to the unwisdom and lack of economy in concentrating on children“. Hilfe müsse, so die Erfahrung, vor allem auf Familien und größere soziale Zusammenhänge gerichtet sein. Interessanterweise wurde auch die Aktion in Deutschland Anfang der 1920er Jahre als „historical accident“ bewertet. Es sei ferner fraglich, „whether the program as it was furthered very much our basic concern of promoting a better world.

70 Heike Wieters, The NGO Care and Food Aid from America 1945-80: 'Showered with Kindness'?, (Manchester: Manchester University Press, 2017).

71 Confidential Memorandum on post-war planning, Foreign Service Section 4 und 5/6/1943, in: AFSCA, AFSC Minutes 1943. 
Our workers had few direct contacts with the people assisted, being mainly in administrative capacities.“ Ein Speisungsprogramm, so die Erkenntnis, sei nicht der richtige Weg, ,if we think in terms of interpreting our basic policy and motivation“. Effizienz und der Anspruch, eine Form der rehabilitation zu leisten, die spirituelle Aspekte berücksichtigte, bildeten eine untrennbare Einheit. ${ }^{72}$

\section{Das AFSC nach 25 Jahren}

Der Zweite Weltkrieg bot viele Gelegenheiten, Bilanz zu ziehen. Während die Welt in Trümmer fiel, blickte das AFSC 1942 auf das erste Vierteljahrhundert seiner Geschichte zurück. Und das AFSC hatte, unbeirrt von allen Rückschlägen, den Test der Zeit bestanden, wie John Rich im Vorwort der Jubiläumsbroschüre „Twenty-Five Years under the Red and Black Star“ befand: „Those who have borne the Quaker Star“ könnten bezeugen, dass das Prinzip, das allem Handeln des AFSC zugrunde lag, namentlich dass Hass und Gewalt am Ende „would give way before the insistent and irresistible forces of love“, vielfach seine Früchte getragen habe. Wenn überhaupt, so sei es die Welt gewesen, die den falschen Weg eingeschlagen habe. Wenn die Kraft der Liebe im Kleinen durch die Aktionen des Komitees Wunder gewirkt, Hunger gestillt und Hoffnung wiederhergestellt habe, „how greatly it would serve mankind when applied as a principle of national and international policy!“73

Die weiteren Seiten der Broschüre boten einen Überblick über vergangene und gegenwärtige Hilfseinsätze, sie berichteten von wiederaufgebauten Dörfern, von Millionen gespeister Kinder und der Arbeit in den Flüchtlingscamps. Insgesamt zeigte die Broschüre, dass das Selbstbewusstsein des AFSC zu gleichen Teilen auf religiöser Überzeugung wie auf den Erfahrungen einer professionell operierenden, wohletablierten Hilfsorganisation gründete. Beides war 1942 bereits eine untrennbare Allianz eingegangen.

Und dennoch: Zwar mochte die Frage, was das AFSC in erster Linie sein wollte - weltlicher Arm einer Glaubensgemeinschaft oder humanitäre Hilfsorganisation mit religiösen Wurzeln - in der Praxis der Hilfseinsätze mehr und mehr ihren Sinn verloren haben. Für die Mitglieder des AFSC war sie jedoch weiterhin so brennend wie in den ersten Jahren. Dies wurde etwa 1943 deutlich, als sich das AFSC auf die Suche nach dem perfekten humanitären Helfer begab. Im Rahmen

72 Confidential Memorandum on post-war planning, Foreign Service Section 4 und 5/6/1943, in: AFSCA, AFSC Minutes 1943.

73 American Friends Service Committee, Twenty-Five Years under the Red and Black Star, (AFSC: Philadelphia, 1942). 
der sich abzeichnenden Zusammenarbeit mit der UNRRA rechnete man mit einem gesteigerten Bedarf an jungen Männern, die das AFSC in die anstehenden Hilfseinsätze nach Europa und Nordafrika entsenden konnte. Für das Komitee galt es nun die Weichen zu stellen, um die passenden Personen zu finden. Ein eigens für die anstehende Rekrutierungskampagne verfasstes Memorandum definierte das Anforderungsprofil. In erster Linie wurden Männer gesucht, die über berufliche Fähigkeiten verfügten, die in den Einsatzgebieten gebraucht wurden. Das Memorandum zählte dazu Erfahrungen in der Kinderfürsorge und der Sozialarbeit sowie Führungserfahrungen in Wohlfahrtseinrichtungen, im Gesundheitswesen und anderen Kommunaleinrichtungen, außerdem in der Buchhaltung, Logistik oder in bestimmten handwerklichen Berufen (wie etwa Kfz-Mechaniker) sowie in der Land- und Forstwirtschaft. Gefragt war weiterhin die Bereitschaft zur rein bedürfnisorientierten Hilfe ohne Ansehen von „race, creed and politics“. Unparteilichkeit „in acutely partisan situations“ und hohe Belastbarkeit in „situations of tension“ gehörten ebenso dazu wie die Bereitschaft, „dull and sacrificial tasks“ diszipliniert und ohne Aussicht auf unmittelbare Anerkennung auszuführen. Ein durch entsprechende Aktivitäten in den USA ausgewiesenes Interesse an sozialen Fragen war erwünscht, ebenso wie Sprachkenntnisse. ${ }^{74}$

Gesucht wurden mit anderen Worten relief worker, deren beruflicher Hintergrund und persönliche Eigenschaften dem Charakter der anstehenden Aufgabe entsprachen. Damit hielt sich das AFSC an Standards, wie sie die UNRRA oder auch das Amerikanische Rote Kreuz für ihre Helfer setzten. Der entscheidende Unterschied bestand darin, dass das Memorandum an diesem Punkt nicht haltmachte. Für das AFSC war es vielmehr wichtig zu betonen, dass es von den „Rekruten“ auch erwarte, dass sie bei ihrer Tätigkeit die Werte der Quäker teilten. Dabei war die Zugehörigkeit zur Society of Friends nachrangig. Dagegen machte bereits das Eingangsstatement klar, dass das AFSC sich „,not primarily (as) a social service organization“ verstehe, sondern vielmehr als „an agency through which members of the Society of Friends and like-minded persons carry into action their deepest religious convictions and insights“. Weiter hieß es hierzu:

Through relief service we are able to express our sense of responsibility for and our sense of unity with our fellow human beings. We feel that we need to bring food, clothing and shelter to those in distress, but far more important than even such vital material assistance is the opportunity to share the burden of suffering of another to aid him recover his sense of selfrespect and integrity, and to help restore a faith in love and good-will through a practical demonstration of human sympathy and brotherhood.

74 Memorandum „Relief work with the American Friends Service Committee“, Department of Personell and Training 24/5/1944, in: AFSCA, AFSC Minutes 1944. 
Überzeugt vom Weg der Gewaltfreiheit und von „creative love“ als Grundlage aller menschlichen Beziehungen suche das AFSC ,in our workers those who share this fundamental attitude and motivation" ${ }^{75}$

Einmal mehr bildeten sich in dieser Jobbeschreibung für den AFSC relief worker der Zukunft die Spannungen ab, die das Selbstverständnis des Komitees auch nach rund 25-jähriger Existenz prägten. Sowohl der Professionalismus einer etablierten Hilfsorganisation als auch die Verankerung in den Werten und Glaubenssätzen einer religiösen Gemeinschaft gehörte zum Markenkern der Quäkerhilfe, bestimmte deren humanitäre Identität und signalisierte gleichzeitig Zugehörigkeit und Eigenständigkeit innerhalb des humanitären Sektors. Die fundamentalen Fragen, die das American Friends Service Committee an seinem Ursprung und während der ersten beiden Dekaden seiner Arbeit begleitet hatten, hatten nichts von ihrer Aktualität eingebüßt und erstreckten sich auf sämtliche vier Bestandteile des Namens: Inwieweit war man bereit, als Vertreter des eigenen Landes, mithin als American relief organisation zu agieren? War das AFSC in seiner Arbeit (noch) als Quäkerorganisation erkennbar? Wenn der Service zu Hause und im Ausland im Zentrum stand, von welcher Art sollte dieser Dienst sein und welche Inhalte sollte er spiegeln? Und zuletzt: In welchem Verhältnis stand das AFSC zur Society of Friends, in welchem Grad repräsentierte es als Komitee tatsächlich die Gesamtheit seiner Konstituenten, sprich: aller Ausrichtungen des Quäkertums über theologische, geografische und politische Gräben hinweg? Keine dieser Fragen hatten die ersten 25 Jahre klar beantwortet, nach wie vor standen sich unterschiedliche und oftmals widerstreitende Tendenzen gegenüber.

Die Widersprüche hatten aber zu keiner Lähmung des AFSC geführt und seine Entwicklung als Hilfsorganisation nicht entscheidend gehemmt. Eher ist das Gegenteil der Fall: Wie das vorliegende Buch zeigen konnte, waren es gerade das Spannungsverhältnis zwischen Professionalismus und dem Anspruch, einen Dienst nach Quäkergrundsätzen zu leisten, sowie die Dialektik zwischen transnationaler Orientierung und nationaler Einbindung, die in verschiedenen Phasen als Antriebskraft der Entwicklung des AFSC wirksam wurden und dessen Identität als humanitäre Hilfsorganisation prägten.

So war die Frage, wie groß das A in AFSC geschrieben werde, sprich: bis zu welchem Grad es sich als Vertreter der USA im Ausland begreife, eine der großen Konstanten in der Arbeit des Komitees. Damit eng verbunden war die Frage nach dem Verhältnis zur US-Regierung und ihren offiziellen und inoffiziellen Vertretern. Das AFSC hatte, wie es J. William Frost formulierte, „begun life on the de-

75 Memorandum „Relief work with the American Friends Service Committee“, Department of Personell and Training 24/5/1944, in: AFSCA, AFSC Minutes 1944. 
fensive“ ${ }^{76}$ Der Anspruch, jungen Quäkern im wehrfähigen Alter eine Alternative für den Dienst an der Waffe zu eröffnen, die gleichzeitig im Einklang mit dem Friedenszeugnis der Quäker und patriotisch war, erforderte gleichwohl eine bis dato nicht selbstverständliche Kooperation mit staatlichen Stellen. In der Folge war es jedoch gerade jene Zusammenarbeit mit dem ARC als quasi-offizieller amerikanischer Hilfsagentur im Krieg sowie mit der ARA Herbert Hoovers in Deutschland, die dem AFSC erst den Raum eröffnete, in dem sich constructive service entfalten konnte. Er erlaubte es den Quäkern, sich eine Reputation als rein humanitäre, den Grundsätzen der Quäker verpflichtete und gleichzeitig zweifelsfrei amerikanische Hilfsorganisation aufzubauen. Herbert Hoover war unter den ersten, die im Rahmen der Kinderspeisungsaktion in Deutschland das Potenzial dieser Position erkannten.

Das AFSC zehrte von diesem anfänglich erworbenen Kapital und setzte es früh zur Festigung seiner Position ein, sowohl bei seinen Hilfsaktionen im Ausland als auch im eigenen Land. Vor allem sein Image als neutrales, rein am humanitären Ziel orientiertes service committee verteidigte das Komitee wiederholt gegen Versuche der Vereinnahmung - sei es von Seiten politischer Aktionsgruppen, wie im Fall Russlands oder im Spanischen Bürgerkrieg, sei es von Seiten der ARA. Allerdings befand sich die immer wieder offen zur Schau getragene Neutralität des AFSC selbst im Wandel. Während Neutralität im Fall der Sowjetunion bedeutete, sich nicht der anti-kommunistischen Ausrichtung der ARA unterzuordnen, bedeutete sie etwa im Spanischen Bürgerkrieg, die Freiheit zu behalten, „to get the job done“. Neutralität hieß zudem etwas anderes, je nachdem ob sie aus der Sicht des AFSC in Philadelphia oder der der Helfer vor Ort definiert wurde. Für Letztere stand die Identifikation mit den Adressaten der Hilfe sowie mit ihren einheimischen Kooperationspartnern - in Deutschland, in der Sowjetunion oder im republikanischen Spanien - nicht notwendigerweise im Widerspruch zu ihrem humanitären Ethos.

Das AFSC blieb bei all dem in mehrfacher Hinsicht eine dezidiert amerikanische Organisation. Das betraf zunächst das enge wechselseitige Verhältnis von auswärtigen und heimischen Aktivitäten. Früh etablierte sich ein kontinuierlicher Austausch von Personal und Ideen. Viele Mitarbeiter des AFSC verfügten über Erfahrungen aus den großen Hilfseinsätzen der 1920er Jahre, die etwa in heimischen Arbeitskonflikten zum Tragen kamen. Umgekehrt flossen Ideen, beispielsweise aus der homestead-Bewegung, in die Hilfe für deutsche Flüchtlinge oder im Spanischen Bürgerkrieg mit ein.

76 Frost, „Our Deeds Carry Our Message“, 6. 
In der Ära des New Deal in den 1930er Jahren wurden auch die Beziehungen zur Regierung enger. Bei seiner Hilfstätigkeit in Spanien war das AFSC bereit in enger Absprache mit dem Weißen Haus als inoffizieller Vertreter der USA sowohl vor Ort als auch im Rahmen des Völkerbundes zu agieren. Als das AFSC im Zweiten Weltkrieg mit anderen privaten Hilfsorganisationen Teil des Hilfsaufwands der US-Regierung und später der UNRRA wurde, erhielt diese Zusammenarbeit in gewisser Weise nur noch ein förmliches Siegel. Zugespitzt ausgedrückt war das AFSC durch die Geschichte der 1930er Jahre prädestiniert, zum Vertreter eines New Deal for the World zu werden.

So einfach lagen die Dinge denn aber doch nicht. Selbst zu Zeiten, als Clarence Pickett freien Zugang zum Weißen Haus genoss, blieb das Verhältnis zur Regierung voller Widersprüche. In der Praxis kollidierte das sorgsam kultivierte Selbstbild als Repräsentant eines konstruktiven und positiven Patriotismus, der zu Hause wie in der Welt die beste Seite der USA vertrat, mit der konkreten Realität amerikanischer Politik. Das Unbehagen, das viele Quäker gegenüber einer Vereinnahmung von Regierungsseite teilten, blieb auch während der Roosevelt-Jahre wach und erhielt unter anderem durch die restriktive Einwanderungspolitik dieser Jahre neue Nahrung. Spätestens mit dem Kriegseintritt der USA Ende 1941 machte sich dann Ernüchterung in diesem Verhältnis breit, auch und nicht zuletzt im Lichte der Erfahrungen mit dem Civilian Public Service und den japanischamerikanischen Zivilinternierten. Während das AFSC Teil der Vorbereitungen für den Aufbau einer humanitären Infrastruktur in der Zeit nach der Befreiung Europas wurde, wuchs auch die Kritik und die Abgrenzung gegenüber staatlichem Handeln.

Der Übergang von Roosevelt zu Truman erscheint in vielerlei Hinsicht als Bruch in den Beziehungen des AFSC zur Regierung. Der Abwurf der Atombomben über Hiroshima und Nagasaki, der Beginn des Kalten Krieges und die aufziehenden McCarthy-Jahre - in denen auch das AFSC zeitweilig in den Fokus der anti-kommunistischen Treibjagd geriet - waren alles Etappen einer fortlaufenden Entfremdung, die sich in den Eisenhower-Jahren nur noch weiter vertiefen sollte. In „Speak Truth to Power“, einem breit rezipierten friedenspolitischen Manifest, formulierte das AFSC 1955 eine beißende Kritik an der in der Logik des Kalten Krieges gefangenen Regierungspolitik, wobei der Ton für einen konfrontativeren Kurs gesetzt wurde, der sich in der Bürgerrechtsbewegung und schließlich im Widerstand gegen den Vietnamkrieg fortsetzen sollte. ${ }^{77}$

77 American Friends Service Committee, Speak Truth to Power, a Quaker Search for an Alternative to Violence; a Study of International Conflict (Philadelphia, 1955). 
Ein zweites Feld, auf dem die Widersprüche im Selbstverständnis des AFSC sichtbar wurden, war die Zusammenarbeit mit den britischen Quäkern. Das Verhältnis zu den britischen Glaubensgenossen stand sinnbildlich für den Zwiespalt zwischen transnationaler Orientierung und nationaler Einbindung.

Auf beiden Seiten des Atlantiks hatten sich mit ausnahmslos allen Hilfseinsätzen der Zwischenkriegszeit Hoffnungen verbunden, die Verbindungen zwischen Quäkern über nationale Grenzen hinweg in einer fellowship of service zu stärken. Damit eng verknüpft war stets die Erwartung gewesen, über eine solche Kooperation den quäkerspezifischen Charakter des eigenen humanitären Engagements zu unterstreichen. War der Wunsch nach einer vertieften Zusammenarbeit mit den britischen Quäkern folglich eine Konstante in der Tätigkeit des AFSC, so traf gleiches auf die Schwierigkeiten zu, diesen Wunsch in der Realität umzusetzen. Ob in Deutschland und Russland nach dem Ersten Weltkrieg oder im Spanischen Bürgerkrieg: Wenngleich die britischen Quäker in all diesen Einsätzen als Türöffner für das AFSC gedient hatten, hatte dieses sich am Ende jedes Mal für eine eigenständige amerikanische Hilfsmission entschieden.

Die Gründe waren vielfältig: Wie gezeigt werden konnte, war es neben den Vorgaben des ARC und der ARA, in dessen Auftrag das AFSC agierte, und neben den Verpflichtungen gegenüber seinen amerikanischen Spendern auch immer wieder ein unterschiedliches Verständnis von den Zielen der Hilfe und der Arbeitsweise, die das Pendel aus Sicht des AFSC zugunsten einer rein ,amerikanischen“ Aktion ausschlagen ließen. Schließlich spiegelten die Beziehungen zwischen den britischen und den amerikanischen Quäkern auch und nicht zuletzt die sich verschiebenden Kräfteverhältnisse zwischen den USA und Großbritannien auf internationaler Ebene wider.

Dies fand seinen Ausdruck nicht zuletzt in der Entscheidung nach 1945, die gemeinsame Arbeit in Asien in Einflusssphären aufzuteilen. Während die indischen Aktivitäten der Friends Ambulance Unit vom britischen FSC weitergeführt wurden, übernahm das AFSC 1945 die Leitung (und vollständige Finanzierung) des China Convoy, der bis zur Machtübernahme der chinesischen Kommunisten 1949 und noch eine kurze Zeit darüber hinaus weiter in West-China tätig blieb. ${ }^{78}$

Bereits zuvor, noch während des Zweiten Weltkriegs, war die Frage der angloamerikanischen Zusammenarbeit nochmals grundsätzlich auf den Prüfstand gekommen. Wenngleich die Stimmen, die für eine Fortführung und Vertiefung (nach Kriegsende) der „special relationship“ mit den Briten plädierten, erneut jene überwogen, die sich für die weitgehende Trennung und einen

78 Gregory A. Barnes, A Centennial History of the American Friends Service Committee (Philadelphia: FriendsPress, 2016, 163-164). 
„American effort“ aussprachen, waren auch die Gründe, die von den Befürwortern ins Feld geführt wurden, vorwiegend pragmatischer Natur. Gerade in Europa, wo das AFSC seinen Haupteinsatzort nach dem Ende des Krieges sah, seien die britischen Quäker weiterhin besser verankert als die Amerikaner. „I don’t think we can get to first base without the British, in Europe“, merkte ein Mitglied des AFSC 1943 an und brachte sein Plädoyer für eine Zusammenarbeit auf die nüchterne Formel: „We have the money, but they have the entry."79

Von ähnlich widersprüchlichen Tendenzen war auch das breitere internationale Engagement des AFSC geprägt: Auch hier befand sich ein internationalistischer Impuls, der nach grenzübergreifender Zusammenarbeit strebte, im Wettstreit mit gegenläufigen Bewegungen, die die Eigenständigkeit des Quäkeransatzes betonten und auf eine Abgrenzung zielten. Vor diesem allgemeinen Hintergrund zeigte sich der Internationalismus des AFSC im Untersuchungszeitraum als höchst wandelbar. Internationale Netzwerke hatten Quäker dabei bereits vor 1917 mit Gleichgesinnten verbunden, etwa in der Anti-Sklaverei- oder der Friedensbewegung. Auf diese Traditionen baute die humanitäre Hilfe der Quäker in der Zwischenkriegszeit auf vielfache Weise auf. So waren die Verbindungen amerikanischer und britischer Quäkerinnen zur WILPF sowie die transnationale Arbeit für die Zivilinternierten während des Ersten Weltkriegs entscheidend am Ausgangspunkt der Kinderspeisungen in Deutschland. Auch in der Sowjetunion agierten die Quäker am Anfang der 1920er Jahre als Teil eines breiten internationalen Netzwerks, dem neben anderen amerikanischen Organisationen wie der ARA und dem JDC auch Save the Children oder das Internationale Rote Kreuz angehörten.

Zum Lackmustest für den Internationalismus des AFSC gerieten wiederholt die Beziehungen zum Genfer Völkerbund. Amerikanische Quäker teilten mit ihren britischen Glaubensgenossen eine skeptische Haltung gegenüber der Weltorganisation. Zweifel bestanden auf beiden Seiten des Atlantiks, insbesondere gegenüber dem friedensstiftenden Potenzial einer Organisation, die mit der Versailler Friedensordnung identifiziert wurde, in der aus Sicht vieler der Keim eines neuen Konflikts bereits angelegt war. Gegen das mit Sanktionen bewehrte Prinzip der kollektiven Sicherheit setzten sie einen „spiritual internationalism“.

Im Netz der internationalen Quäkerzentren, das seit den 1920er Jahren in Europa entstanden war, bildete sich deshalb der Versuch ab, einem quäkerspezifischen Internationalismus Form und Inhalt zu geben. Über Ansätze, message work gegenüber einem breiteren Milieu von „Gleichgesinnten“ in ihren Gastlän-

79 Confidential Memorandum on post-war planning, Foreign Service Section 4 und 5/6/1943, in: AFSCA, AFSC Minutes 1943. 
dern zu betreiben, kamen die meisten dieser „Quäkerbotschaften“ allerdings nicht hinaus. Dagegen wurden einige dieser Zentren während der 1930er Jahre zu Knotenpunkten im breiteren internationalen Netz der europäischen Fluchthilfe und Teil einer bedeutenden humanitären Infrastruktur, allerdings ohne spezifischen Quäkeranstrich.

Daneben wuchs ab Mitte der 1920er Jahre das Interesse des AFSC am Völkerbund spürbar. Dieser Wandel machte sich sowohl in der Friedensarbeit im eigenen Land, in der enger werdenden Verbindung zum Genfer Quäkerzentrum sowie nicht zuletzt in der Zusammenarbeit mit den Flüchtlingskommissionen des Völkerbundes für Deutschland und Spanien bemerkbar. Parallel zur Annäherung an den Staat in den Jahren des New Deal wurde der Internationalismus des AFSC nun proaktiver. In der Flüchtlingshilfe übernahm das Komitee als amerikanische Hilfsagentur die Rolle eines Brokers zwischen dem Völkerbund einerseits sowie Regierung und Spendern in den USA andererseits.

Umgekehrt bildete sich in der Mitarbeit des AFSC in der Flüchtlingsarbeit des Völkerbundes während der 1930er Jahre ein breiterer Trend der humanitären Hilfe der Zwischenkriegszeit ab (ein Prozess, der zumindest in den USA ebenfalls seine Entsprechung auf nationaler Ebene hatte). Private Organisationen wie das AFSC fanden sich nun zunehmend in internationale Mechanismen der Hilfe eingebunden.

Seinen deutlichsten Ausdruck fand dies in der Übernahme der Führung der International Commission for Child Refugees durch das AFSC im Gefolge des Spanischen Bürgerkriegs. Von dort führte der Weg zur Kooperation der Quäker mit der UNRRA, die sich nach dem Krieg in der Arbeit für Displaced Persons fortsetzte und schließlich bis nach Gaza. Dort übernahmen die Quäker 1948 im Gefolge des Arabisch-Israelischen Krieges im Auftrag der Vereinten Nationen die Verantwortung für die Versorgung in den palästinensischen Flüchtlingslagern. Dieser Einsatz, der außerhalb des zeitlichen Rahmens der vorliegenden Studie liegt, verdient gleichwohl aus zweifachem Grund Erwähnung. Zum einen warf die Hilfsoperation zugunsten Zehntausender vertriebener Palästinenser - unter der Aufsicht des ägyptischen Militärs und unter dem Blick einer zutiefst polarisierten internationalen Öffentlichkeit - brennende Fragen hinsichtlich der Neutralität der Quäker auf, deren Echo noch im gegenwärtigen Engagement des AFSC im Nahen Osten nachhallt. Zum anderen warf es aber auch ein Schlaglicht auf das hohe internationale Renommee, welches die Quäker zu diesem Zeitpunkt genossen und das sich unter anderem auch in der Verleihung des Friedensnobelpreises 1947 an das AFSC und den britischen FSC zeigte. ${ }^{80}$ Dass Harold Evans, ein

80 Die Quäker erhielten den Friedensnobelpreis im Übrigen als Religionsgemeinschaft, mit den 
Mitglied des AFSC Board, von den Vereinten Nationen parallel zum Einsatz in Gaza für den Posten des municipal commissioner Jerusalems angefragt wurde (das AFSC lehnte aufgrund der militärischen Implikationen ab), war nur ein weiterer Beleg für das hohe Ansehen und das Vertrauen in die Neutralität des AFSC. ${ }^{81}$

Die Gründung der UNO im Frühjahr 1945, an der eine Delegation des AFSC teilnahm, begrüßten die Quäker mit einer Mischung aus Zuversicht und Kritik. Ein gemeinsam mit den britischen Friends verfasstes Memorandum für die Delegierten der Gründungskonferenz in San Francisco lobte das friedensstiftende Potenzial der neuen Weltorganisation, das man vor allem in der Schwerpunktsetzung auf die wirtschaftliche, soziale und kulturelle Zusammenarbeit sowie im Wiederaufbau, in der Armutsbekämpfung, in der Bildung und der internationalen Kontrolle der Rohstoffe sah. Die neue Sicherheitsarchitektur war dagegen aus Sicht der Quäker das Sinnbild eines „cynical age“, eines Zeitalters, das alleine auf Gewalt vertraue und sich für neue Kriege rüste, anstatt eine „new world on moral foundations“ $\mathrm{zu}$ bauen. ${ }^{82}$ Manifest wurden das fortgesetzte Interesse und der Wille, die Sichtweise der Quäker in die Gestaltung der internationalen Ordnung einzubringen, nicht zuletzt in der Einrichtung eines Quaker Office am Sitz der Vereinten Nationen in New York 1947, in dem die Arbeit des (weiterbestehenden) Genfer Zentrums der Zwischenkriegszeit eine Fortsetzung erfuhr. ${ }^{83}$

Schließlich stellte sich die Frage nach der Identität des AFSC als Hilfsorganisation auch und nicht zuletzt im Verhältnis zur Gesamtheit der Quäker in den USA. Der Anspruch, als einigende Kraft innerhalb einer theologisch wie politisch von tiefen Gräben durchzogenen Glaubensgemeinschaft zu wirken, hatte das AFSC von Anfang an begleitet und war auch während des Zweiten Weltkriegs noch präsent. Andererseits war die Kritik insbesondere konservativer, aber auch evangelikaler Friends am aus ihrer Sicht zu liberalen, sozialaktivistischen und im

beiden Service Committees als Vertretung, was wiederum vor allem in den USA zu Diskussionen über das Verhältnis von Quäkerschaft und AFSC führte. H. Larry Ingle, „The American Friends Service Committee 1947-49: The Cold War’s Effect“, in: Peace\&Change 23, no. 1 (2007).

81 Einen guten Überblick über den Einsatz bietet Nancy Gallagher, Quakers in the Israeli-Palestinian Conflict: The Dilemmas of Ngo Humanitarian Activism (Kairo/New York: The American University in Cairo Press, 2007). Ausgesprochen kritisch bewerten den Einsatz dagegen Asaf Romirowsky und Alexander H. Joffe, Religion, Politics, and the Origins of Palestine Refugee Relief (New York/London: Palgrave Macmillan, 2013). Speziell zum Einsatz in Gaza und zur quäkerspezifischen Form der Hilfe aus anthropologischer Sicht erhellend ist Ilana Feldman, „The Quaker Way: Ethical Labor and Humanitarian Relief“, in: American Ethnologist 34, no. 4 (2007).

82 Statement des Meeting of Sufferings of the Religious Society of Friends in Great Britain for the delegates to the San Francisco conference 2/3/1945, in: AFSCA, AFSC Minutes 1945.

83 Stephen Collett, Sixty Years with the UN in New York. A History of the Quaker UN Office (New York: Quaker United Nations Office New York, 2007). 
Kern „säkularen“ Profil des Komitees niemals gänzlich verstummt. Die Kompromissformeln, welche seit der Reorganisation 1929 die Verbindung des AFSC mit den Quäkergemeinden im Land sicherstellen sollten, hielten die Organisation vielmehr in einem prekären Gleichgewicht, das während der 1930er Jahre immer wieder zu kippen drohte - aufgrund der Annäherung an die Politik des New Deal und des progressiven Impetus, der die homestead-Bewegung, die student-in-industry-Programme, die Institutes of international relations und die peace caravans antrieb. Daran änderte auch nichts, dass sich das AFSC in seinen Publikationen weiterhin als tief in der religiösen Tradition der Quäker verwurzelte Organisation präsentierte. Auch die humanitäre Arbeit in Europa erschien in den Darstellungen des AFSC durchgehend als von christlichen und quäkerspezifischen Motiven getrieben. ${ }^{84}$ Die Praxis der Arbeit, zu Hause wie im Ausland, war es, die aus der Sicht vieler Friends im Land eine andere Sprache sprach. So konnte es kaum verwundern, dass ein Memorandum zu Beginn des Zweiten Weltkriegs eine während der vorangegangenen 20 Jahre immer wieder von neuem aufgegriffene Frage aufwarf: „How can a more organic relation be worked out between the AFSC and Quakers in different parts of the country?" Viele der Quäker im Lande, so stellte das Positionspapier alarmiert fest, verstünden schlicht nicht, was die Arbeit des AFSC mit Religion zu tun habe. Welche Antwort konnte solchen Friends gegeben werden? Wie konnte Quäkern der unterschiedlichen Ausrichtungen die Botschaft übermittelt werden, „that the Service Committee work is their work“? ${ }^{85}$ Es war nicht die letzte Gelegenheit, bei der diese Frage gestellt werden würde.

Der Krieg übertünchte in den folgenden Jahren vieles. Zur Arbeit für die Flüchtlinge kam jene in den Civilian Public Service Camps hinzu, in den Clothing Committees und viele andere Aktivitäten, die Quäker aller Richtungen betrafen und die das AFSC enger an die Gemeinden im Land rücken ließ. Aber das grundsätzliche Problem blieb weiterhin bestehen. Auch in der Nachkriegszeit würde sich das AFSC immer wieder kritischen Fragen hinsichtlich seiner Verankerung innerhalb der Gesamtheit der Quäker in den USA stellen müssen. Dabei spielte nach 1945 auch die weitere Professionalisierung des AFSC als eine national und international expandierende Hilfsorganisation eine gewichtige Rolle. „No one should look toward a permanent position in relief work with the AFSC“, hatte es noch in der eingangs zitierten Stellenausschreibung für Quäkerhelfer von 1943 geheißen, wohl wissend, dass ein solcher Schritt notwendigerweise mit einer weiteren Verwässerung des Quäkercharakters des Komitees verbunden wäre. Von

84 Die Jahresberichte des Komitees begannen stets sowohl mit Verweisen auf die christlichen Wurzeln des Komitees als auch mit direkten religiösen Bezügen wie Bibelzitaten.

85 Memorandum „Relief work with the American Friends Service Committee“, Department of Personell and Training 24/5/1944, in: AFSCA, AFSC Minutes 1944. 
solchen Beschränkungen konnte in der Nachkriegszeit keine Rede mehr sein. Bald stellten Nicht-Quäker die Mehrheit der Mitarbeiter des AFSC, sowohl in der Zentrale in Philadelphia als auch im Feld. Dies war einer der Gründe für die erneuten Debatten um die Quäkeridentität des AFSC, die in den 1970er Jahren in einen weiteren intensiv ausgetragenen Streit um die Ausrichtung des AFSC mündeten und im Wesentlichen bis in die Gegenwart fortgesetzt wurden. ${ }^{86}$ Während das AFSC in Europa und darüber hinaus in den Augen von vielen Millionen Menschen zum Gesicht der amerikanischen Quäker und der Society of Friends geworden war, blieb hinter den Beziehungen des Komitees zu den Quäkern im eigenen Land stets ein dickes Fragezeichen stehen.

Am Ende stand erneut die Frage nach den Motiven. Am 5. Mai 1945 begann die Sitzung der Foreign Service Section mit einer kurzen Andacht. Das Protokoll vermerkte, dass die Gedanken an diesem Morgen zuerst an jene gingen, die gemeinhin als „our enemies“ bezeichnet würden, ,as the AFSC has a peculiar responsibility to consider service for them“. Es folgte eine Lesung aus der Bergpredigt, die mit den Worten endete: „Blessed are the peacemakers.“87

In diesen Tagen im Mai 1945, in denen der Krieg in Europa endete, schloss sich aus Sicht vieler im AFSC erneut ein Kreis: Wie nach dem Ersten Weltkrieg verbanden sich mit dem Kriegsende die Hoffnung und die Erwartung, die Fesseln der vorangegangenen Jahre lösen zu können und zu einem Dienst zurückzukehren, der in allem den Grundsätzen der Quäker entsprach und ihnen keine schmerzhaften Kompromisse mehr abverlangte. Wie nach dem Ersten Weltkrieg wandte das AFSC seinen Blick den vormaligen Feinden zu, und wie damals schien die Hilfe für die „unpopular groups“, unter den Vorzeichen der Versöhnung über die Gräben des beendeten Krieges hinweg, einen Ausweg zu bieten, um gleichsam zu sich selbst zurückzufinden.

Dabei war der Dienst, auf den sich das Komitee im Frühjahr 1945 vorbereitete und den es tatsächlich noch im selben Jahr - zunächst in Deutschland, dann auch in Japan (wo der Krieg im August endete) - antreten sollte, um keinen Deut weniger spannungsgeladen als die Hilfsoperationen der Vergangenheit. Vielmehr stellten sich dieselben Fragen, die jene Einsätze begleitet hatten, mit neuer Dringlichkeit. Insbesondere war zweifelhaft, ob constructive service im Sinne der Quäker unter einem Besatzungsregime möglich sein würde, das Clarence Pickett

86 H. Larry Ingle, „,Truly Radical, Non-Violent, Friendly Approaches‘. Challenges to the American Friends Service Committee“, in: Quaker History 105, no. 1 (2016). Chuck Fager, „Introduction: Quaker Service at the Crossroads“, in: Chuck Fager (Hrsg.), Quaker Service at the Crossroads: American Friends, the American Friends Service Committee, and Peace and Revolution (Falls Church, VA: Kimo books, 1988).

87 Meeting Foreign Service Section 5/5/1945, in: AFSCA, AFSC Minutes 1945. 
selbst in einem Schreiben an Präsident Truman im September 1945 als „,inherently evil“ bezeichnete, insofern es auf einer Haltung von „ridicule and recrimination“ gegenüber den Besiegten fuße, einer Haltung, die wiederum von einer ,wave of hatred and vengefulness“ in den USA selbst getragen werde. ${ }^{88}$

Warum also war das AFSC bereit und sogar bemüht, sich für eine Unternehmung zur Verfügung zu stellen, bei der es drohte, als bloßes Feigenblatt und nützliches, freundliches Gesicht der amerikanischen Besatzungsmacht zu dienen? Darauf gab es keine einfache Antwort, 1945 ebenso wenig wie 1917, 1941 oder zu irgendeinem anderen Zeitpunkt. Die Motive, die das AFSC antrieben, waren wie so oft zuvor vielfältig, zweideutig und teilweise widersprüchlich. In ihnen spiegelte sich nicht nur die Entwicklung des AFSC selbst im Untersuchungszeitraum wider, sondern in mannigfacher Weise jene des gesamten humanitären Sektors (in den USA und bis zu einem gewissen Grad darüber hinaus): Sie bewegte sich zwischen den beiden Polen eines gewachsenen Selbstbewusstsein privater Akteure einerseits und deren vermehrter Einbindung in die staatliche Außenpolitik andererseits. Humanitäre Hilfe war zu einem zunehmend professionell betriebenen, im Kern technisch-säkularen Unternehmen geworden, das dennoch weiterhin, implizit oder explizit, von einem zutiefst religiösen Impetus getragen wurde.

Für das AFSC galt vor diesem Hintergrund: Während die Hilfe für Zivilisten in Deutschland und Japan das Selbstbild der Quäker stärkte, positionierte sich das AFSC gleichzeitig auch auf einem expandierenden und zunehmend umkämpften humanitären „Markt“, indem es als professionelle Hilfsorganisation eine spezialisierte Aufgabe übernahm, namentlich die Versorgung der „unpopular groups“. Doch damit nicht genug: In seinem Schreiben vom September 1945 mahnte Pickett Truman, dass es nun nach Ende des Krieges in Asien nicht allein Japan sei, „that is on trial“. In einem tieferen Sinn sei dies auch für die USA der Fall: „We are the victors. We are a Christian nation. We are the exponents of a democratic way of life, and we have set before the world the ideal of the four freedoms“, mahnte Pickett den Präsidenten. ${ }^{89}$

Es ging den Quäkern in diesem Sinn nicht allein darum, einen Hilfsauftrag im Namen der Regierung auszufüllen. Es ging dem AFSC auch nicht darum, als bloßes Korrektiv der Besatzungspolitik zu agieren. In seinem Selbstverständnis repräsentierte das AFSC nichts weniger als die Idee eines besseren Amerika.

88 Clarence Pickett an Präsident Truman 18/9/45, in: AFSCA, AFSC Minutes 1945. 89 Clarence Pickett an Präsident Truman 18/9/45, in: AFSCA, AFSC Minutes 1945. 